\title{
Material analysis versus historical dye recipes: ingredients found in black dyed wool from five Belgian archives (1650-1850)
}

\author{
Natalia Ortega Saez ${ }^{1, *}$, Ina Vanden Berghe ${ }^{2} \mathbb{1}$ \\ Olivier Schalm¹ ${ }^{1}$, Bert De Munck ${ }^{3}$, Joost Caen ${ }^{1}$ \\ ${ }^{1}$ University of Antwerp, Faculty of Design Sciences, Heritage Department, Campus Mutsaard, Blindestraat 9, \\ 2000 Antwerp, Belgium \\ ${ }^{2}$ Royal Institute for Cultural Heritage (KIK/IRPA), Jubelpark 1, 1000 Brussel, Belgium \\ ${ }^{3}$ University of Antwerp, Faculty of Arts, History Department, Grote Kauwenberg 18, 2000 Antwerp, Belgium \\ *natalia.ortegasaez@uantwerpen.be
}

\begin{abstract}
The relationship between bibliographic and archival research, on the one hand, and object-based study, on the other, forms a very important basis for research into historical production techniques. Several written sources provide insight into the recipes for dyeing black in the past. Yet, this does not guarantee that these written recipes are representative of an entire society or were used in the dyers practice. The way to assess how closely practical dyeing and written sources are aligned entail the chemical analysis of historical textiles. This article focuses on the identification of the ingredients used to dye wool black in the case of well-preserved and dated (1650-1850) historical textiles from five Belgian archives and some remaining historical artefacts. The results are compared with the technical knowledge of dyeing and the ingredients mentioned in written sources from the same period. The aim is to refine the knowledge of the different black dye ingredients used in practice in Northwest Europe during the period.
\end{abstract}

Análise material versus receitas históricas de tingimento: os ingredientes identificados em lã tingida de preto proveniente de cinco arquivos belgas (1650-1850)

\section{Resumo}

A relação entre a investigação bibliográfica e arquivística e a investigação baseada em objectos históricos constitui um ponto de partida fundamental para o estudo de antigas técnicas de produção. Várias fontes documentais dão uma imagem de como se tingia de preto no passado. Contudo, nada garante que estas receitas sejam representativas de uma sociedade no seu todo ou que fossem praticadas pelos próprios tintureiros. A análise química de têxteis históricos constitui um método eficaz para verificar a proximidade entre práticas de tingimento e fontes documentais. Este artigo foca-se na identificação dos ingredientes usados no tingimento de lã com cor preta num conjunto de têxteis históricos datados (1650-1850) e em excelente estado de conservação de cinco arquivos belgas e noutros objectos históricos. Os resultados são comparados com o saber tecnológico associado aos métodos de tingimento e aos ingredientes descritos segundo as fontes documentais da época. O objectivo é o de afinar o conhecimento sobre os ingredientes usados no tingimento de preto no noroeste da Europa durante o período em questão.

\section{Keywords}

Black dyeing

Wool

Belgian Archives

Logwood

Tannin

Indigo

Iron mordant

\section{Palavras-chave}

Tingimento de preto Lã

Arquivos belgas

Pau-de-campeche

Taninos

Anil

Mordente de ferro 


\section{Introduction}

\section{Bibliographical sources of black dyeing}

The historical recipe research on black dyed wool comprising the $1680-1850$ period was based on the investigation of secondary literature in that period, during a PhD study [1]. The industrial period with the start of the use of synthetic dyes and chrome mordants is not part of this article, however.

The study focused mainly on literature recipes for black dyeing in Northern, Western and Southern Europe [2-15]. Many of these North-Western European recipes date back to Antiquity [16, p. 37; 17, p. 62]. The Low Countries, mainly the County of Flanders, the Duchy of Brabant and the County of Holland were the most prominent and most famous European regions for the production and finishing of woollen cloth from 1200 to 1700 [18, p. 122]. Therefore, the urban regulations and technological literature from towns such as Antwerp, Mechelen and Ghent, in present-day Belgium, Hondschoote, in presentday France (Département Nord, French Flanders), the Southern Netherlands, and Amsterdam, Leiden and Delft, in the Northern Netherlands, were important sources for this research. Information and ingredients were found in books of secrets, manuals for dyers, copies of manuscripts, encyclopaedias, and regulations. Most of these recipes contain sufficient information of chemistry, dyes and dyeing practice to be used for reconstructions.

\section{Historical recipes and technology of black dyeing}

Throughout the European countries, the same methods for black dyeing of wool were employed with minor variations by region [19, pp. 410-481; 20, pp. 328329]. De Graaff distinguished two types of black dyeing processes:

\footnotetext{
There are two ways of obtaining a black colour on textiles: (a) dyeing dark blue with woad or indigo and a second dyeing with madder on an alum mordant and (b) mordanting with an iron compound and dyeing with a tannin-containing plant material (gallnut, alder bark or sumac) [19, p. 315].
}

The use of various kinds of ingredients influenced the colour and the quality of the finished product. Dyeing with metal salts, tannin, woad and madder had already been practised since the Middle Ages. The respective guilds always tried to regulate the dyeing process while the dyers themselves were constantly looking for cheaper raw materials for economic reasons. The discovery of new, more competitive products and changing fashions, with a demand for even more varying shades of black, made it impossible to limit dyeing to the imposed and more expensive native raw materials. Both factors gradually brought about a fundamental change in the practice of black dyeing. During the eighteenth century, dyers were allowed to use a combination of a blue undertone dye and a treatment with metal salts. From the seventeenth century until the invention of synthetic dyes (1856), most black dyeing was done with tannins and iron compounds. In many cases, a blue undertone was required and applied with the blue dye logwood. Unfortunately, nowadays these popular black dyeing methods pose many conservation problems with respect to dye and fibre degradation [21].

\section{Preservation of historical black woollen textiles}

Most historical textiles from the sixteenth and seventeenth century did not survive the ravages of time and are otherwise often difficult to date, especially when dyed in a uniform colour without any figuration or pattern. This is since textiles were recycled and incorporated into costumes or furnishing fabrics over the centuries. Moreover, with tapestries as exception, no dates or signatures can be found on textiles. Well-documented black dyed woollen textiles from that period are extremely rare in present-day Belgium and the Netherlands. Only a few examples are known, such as two seventeenth century black woollen doublets from the Rijksmuseum in Amsterdam [20, pp. 313-323] and a few samples of black wool preserved in sixteenth and seventeenth century Flemish tapestries [22, pp. 22-38]. Usually (black) textiles are articles of use that were not created as objects of art. Textile findings obviously have an archaeological context but most often lack any clear frame of reference, origin, exact date of manufacture or information of the artisan or designer. Costumes and accessories can be stylistically placed in a certain period but, again, in most cases there is no signature or date. Given these factors, it is difficult to allocate representative samples to a certain period.

In the attempt to obtain historical woollen textiles from known timespan, the principal present-day Belgian archives and textile museums in the region of the city of Antwerp were consulted and samples were taken from archival documents with accompanying wool references, either well-dated or attributed to a certain period. Although it is not possible to determine exactly where the samples were woven and dyed, it may be assumed from the written sources that the production was situated in Western Europe, more specifically England or the Southern Netherlands. These textiles are still in good condition as they have been preserved from light degradation during their storage in the dark, well-conditioned archives. Due to the scarcity of the samples, it was not possible to consider the quality and type of fabric. High-quality fabrics were supposedly made of high-quality wool and dyed with high-quality ingredients and procedures. One can assume that the samples are high quality because they were found in trade letters and sample books, although this could only be assessed if dyeing recipes were included. On the other hand, it is generally known that English wool was frequently dyed in Antwerp by Antwerp dyers [23, p. 479].

In addition to the archival wool fabrics, four historical black artefacts were added to the study, found in the 
Convent of the Women's Apostles in Antwerp, belonging to Agnes Baliques (last quarter of the seventeenth century).

\section{Goal}

This article will deal with the chemical material analysis of a collection of fifty-one historical black woollen textiles from the archives and artefacts from the 1650 to 1850 period with the aim to gain information about the applied organic and inorganic ingredients. The organic dyes were analysed with high-performance liquid chromatography with photodiode array detection. Chromatographic separation techniques are micro-destructive techniques which allow the identification of different organic dye and degradation molecules, based on the comparison of their characteristic eluting time and UV-VIS absorbance (and/or mass spectrum if such equipment is available) with those from known dye molecules. Although micro-destructive, these analytical techniques are to be preferred on historical samples as they are most efficient for detecting and identifying the individual components in dye mixtures, even in case of very similar molecules [24-31]. Solvents such as dimethyl formamide or dimethyl sulfoxide are preferred for the extraction of the marker molecules of indigoid dye sources, especially when molluscs are to be expected [3235]. These solvents have the disadvantage that they are not able to extract mordant dyes. As multiple mordant dyes and tannins play a significant role in historical black dyeing recipes, acidic extraction was chosen for dye extraction in this study, hence allowing the detection of dyes from both chemical dye classes in the same extract [32].

The inorganic elements were investigated by means of element analysis with scanning electron microscopy with an energy dispersive X-ray detector, an established micro-invasive technique for element analysis of various artefacts. On historical textiles, it is used most often for the identification of the composition of metal threads or for the detection of elements that can be related to the practice of using metal mordants $[21,36]$.

The obtained organic and inorganic constituents from this study were compared with the ingredients mentioned in the historical recipes and prescribed in the regulations. The goal of this study is to improve and/or refine our knowledge of the variations in black dyeing methods that

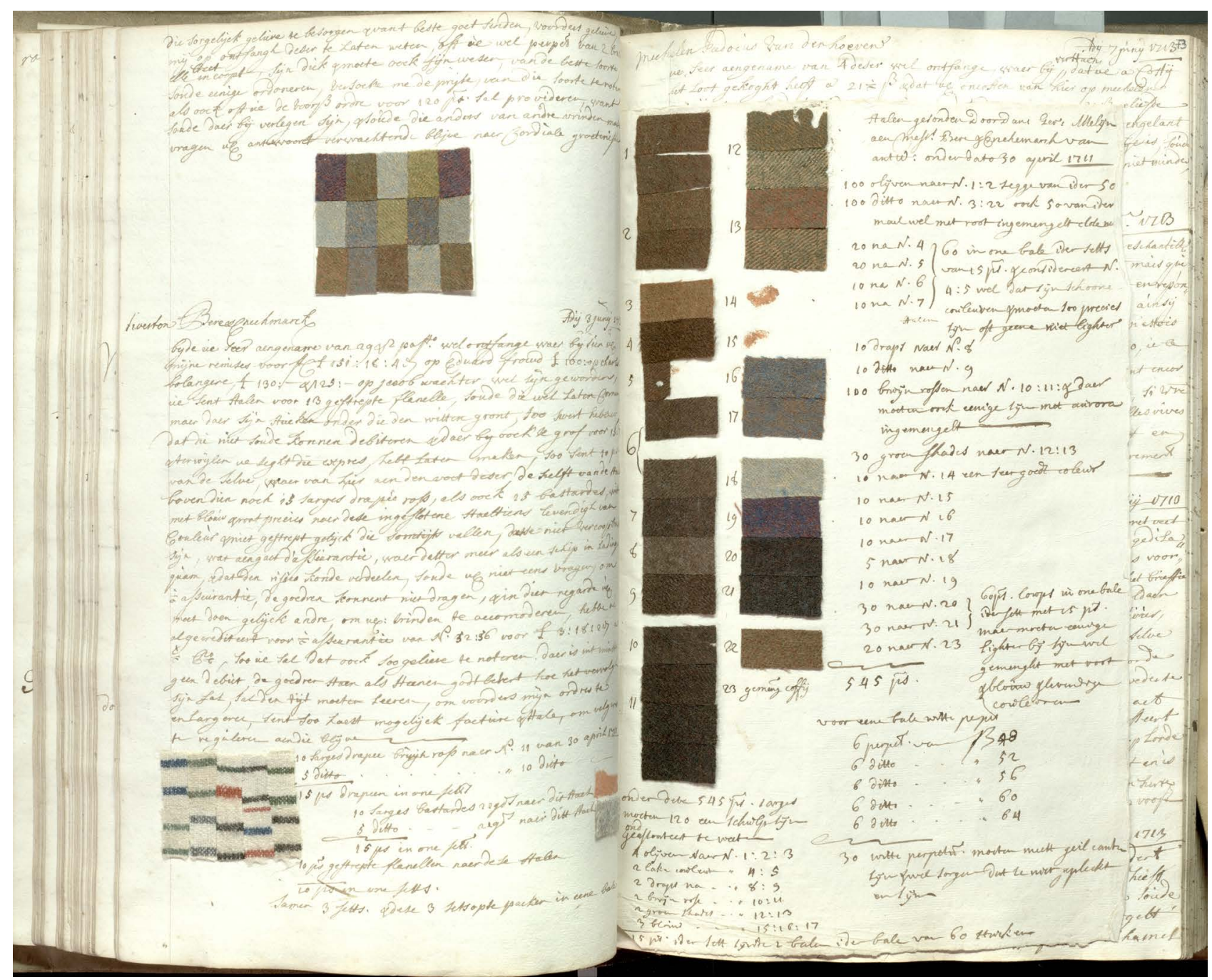

Figure 1. Archive Melijn, Book T94/189, 1712-1714. 
were applied in practice in Northwest Europe between 1650 and 1850.

\section{Classification of historical recipes for dyeing black}

A classification of the historical recipes for black dyeing was made from the bibliographic sources in the described geographical and historical context, by considering the presence or absence of certain ingredients. Detailed discussion of the ingredients found in the black dyeing recipes from historical sources is not part of this publication and was published elsewhere [1]. Three main groups of dyeing were distinguished, each with small variations in minor ingredients.

Type I dye recipes concern a two-stage dyeing procedure by which wool was dyed with a blue undertone by the use of the vat dyes from the indigo (Indigofera tinctoria L.) or woad (Isatis tinctoria L.) plants in different gradations. A minimum degree of intensity of the blue ground was a prerequisite for obtaining a solid dark blue undertone and was obtained by dipping the cloth several times into the dye vat. Hereafter, the wool was mordanted with alum and/or tartar and top-dyed with the red dyes from madder. Yellow mordant dyes such as weld (Reseda luteola L.) among others, were added to the dye bath to save on expensive material or to shade the black colour.
Recipes based on black dyeing with tannin form the basis of the Type II dye recipes. Tannins from various plants such as gallnuts, alder bark, sumac (Rhus species) or redoul (Coriaria myrtifolia L.) were combined with metal salts such as copperas. Copper red and copperas or green vitriol (koperrood in Dutch) were common ingredients for dyeing black, saddening or making a colour duller [20, p. 42]. Such dyeing could be done on a light blue undertone or on undyed wool. Green vitriol contains iron(II) sulphate, although partially also copper sulphate is present. Dyeing with tannin and green vitriol was already known since the Middle Ages in Europe to cause severe fibre damage and was therefore prohibited by regulations in all important wool cloth production centres [19, pp. 39-41]. Furthermore, also iron acetate was often used for black dyeing, as it was easy and cheap to produce. Iron swarf, rusty old nails, filings and dust from the grinding of edge tools in acetic acid form the basic materials to produce iron acetate.

The last main black dyeing group, Type III, comprises combinations of one or more blue dye source(s), either indigo, woad and/or logwood (Haematoxylum campechianum L.), together with tannins and metal salts. Apart from that, red dyes, such as madder (Rubia tinctorum L.) and redwood (Caesalpinia species), and yellow dyes, such as weld (Reseda luteola L.) or dyer's greenweed (Genista tinctioria L.), among others, were used to shade the black colour [1].
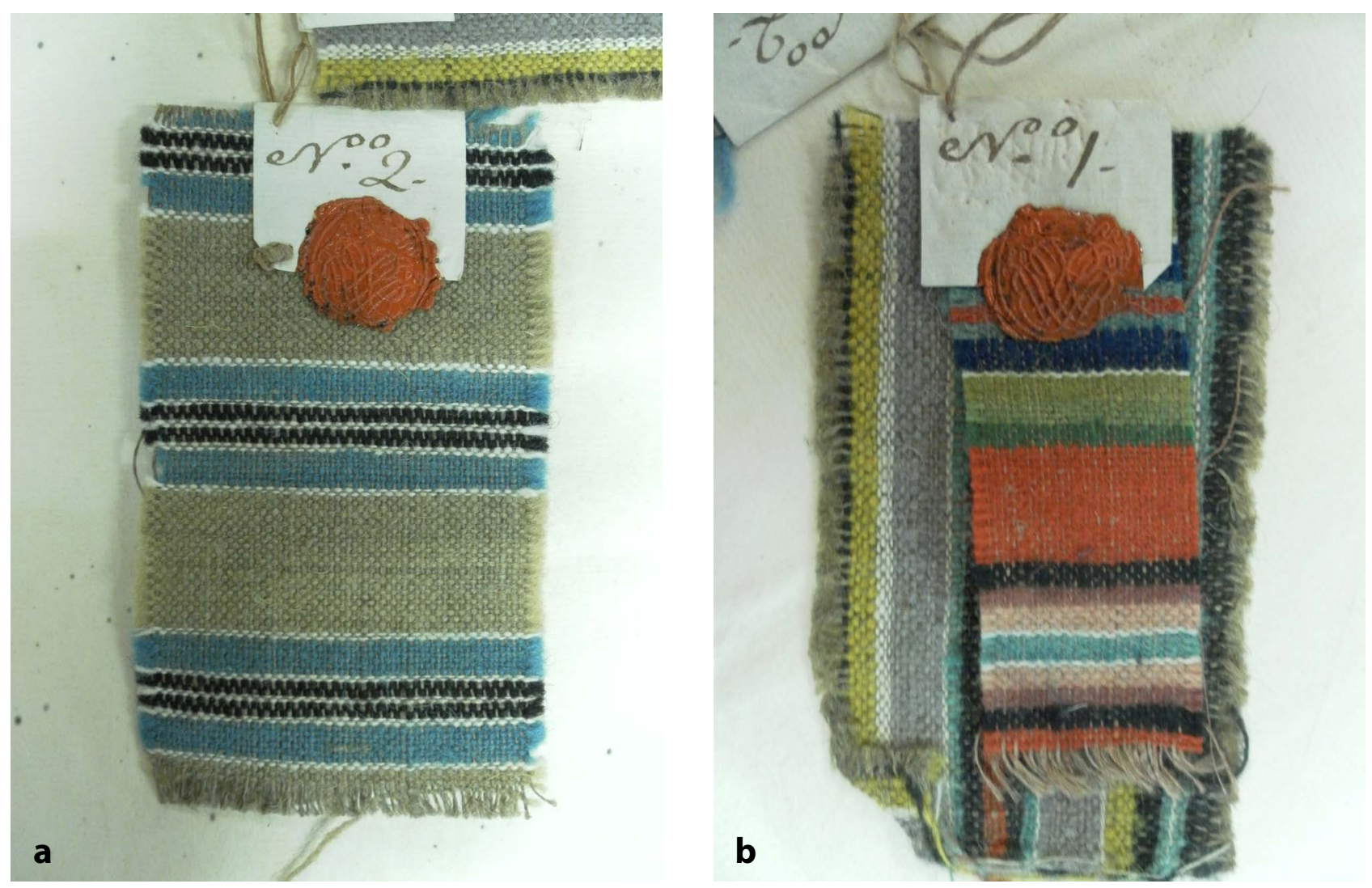

Figure 2. Samples from the craft of linen weavers GA 4202, 1757: a) W35a; b) W35. 


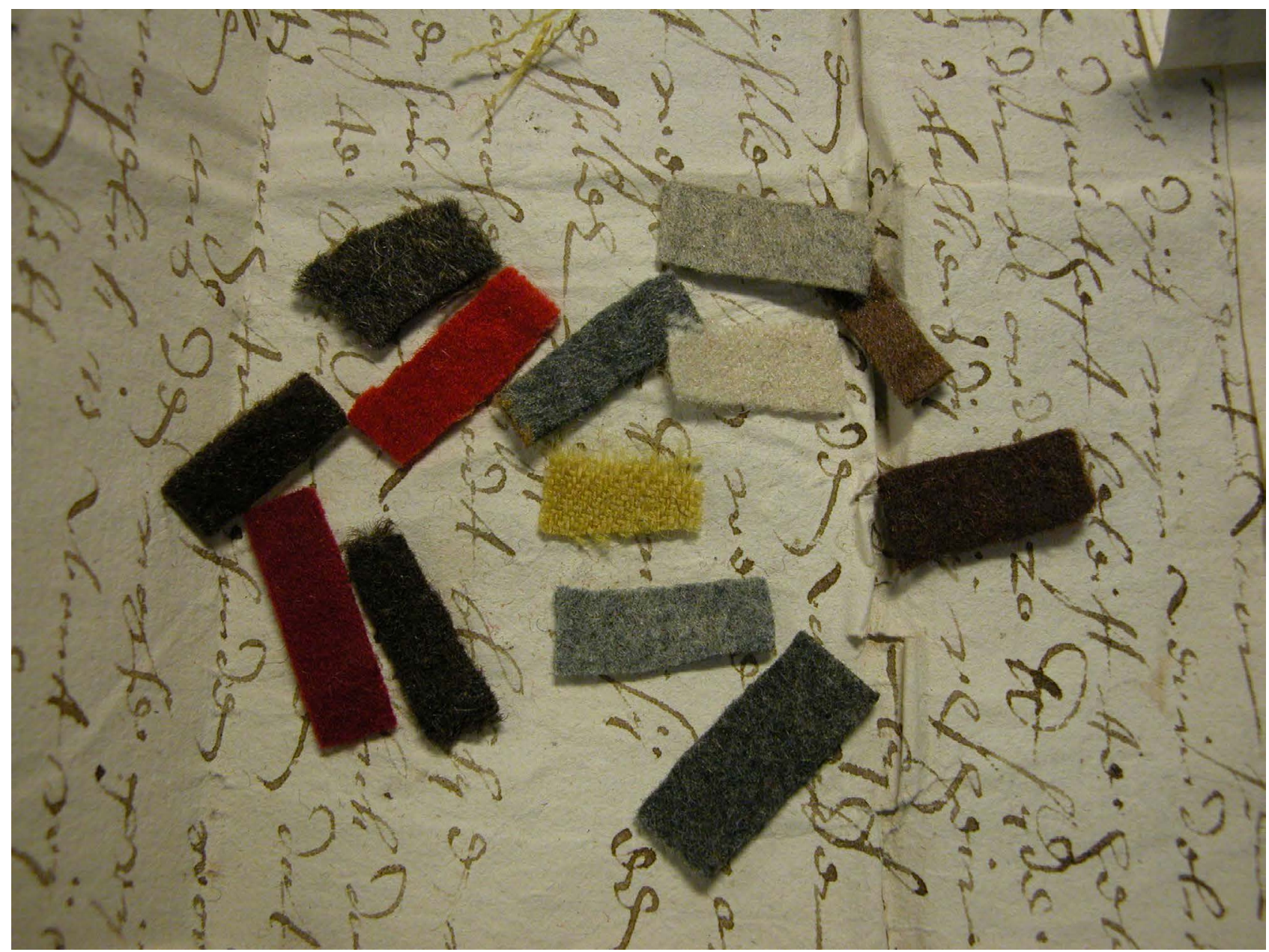

Figure 3. Knijff family archives samples, c.1683, with three black samples (W92, W38 and 38a).

The three types of recipes are derived from historical sources. However, the majority of the written recipes describe Types II and III, while recipe Type I, considered as the most exclusive way to dye black, is only mentioned in very few recipes, probably because most written sources were not published for dyers but for household purposes and will therefore not reveal the professional details of two-stage dyeing of black [3, p. 190].

According to municipal regulations in the considered timespan, mainly of the city of Antwerp, Type I was the preferred way to dye black and was strictly regulated, while Type II was absolutely prohibited for wool dyeing and only allowed for application of silk. From the end of the 17th century onwards, Type III recipes were described for black dyeing of wool as well [1].

\section{Chemical material analysis}

\section{Materials}

Fifty-one historical wool samples with a deep brown and black colour were collected. Depending on the accuracy of dating information, they were attributed to the category of well-dated historical samples, historical textiles attributed to a certain period or to historical artefacts.

\section{Well-dated historical textiles}

The well-dated historical textiles were found in archives attached to a written document which was time stamped. It concerns commercial correspondence, inventories and family archives. To this group belong nineteen samples from the Melijn Archive (1681-1714), ten samples from the Antwerp City Archive (1675-1777) and five samples from the Belgian National Archive (1683-1696).

\section{Melijn Archive, Fashion Museum Antwerp, 1681-1714}

The Melijn Archive consists of a number of trade letters and is located partially in the Fashion Museum of Antwerp and in the Municipal Archives of Wijnegem [37]. Only letters with samples were consulted as well as journals and commercial correspondence (Figure 1). In this commercial correspondence, fabrics were described and orders were written down, giving an idea of the trading activities such as the different trade contacts, the weavers, the dyers, the 

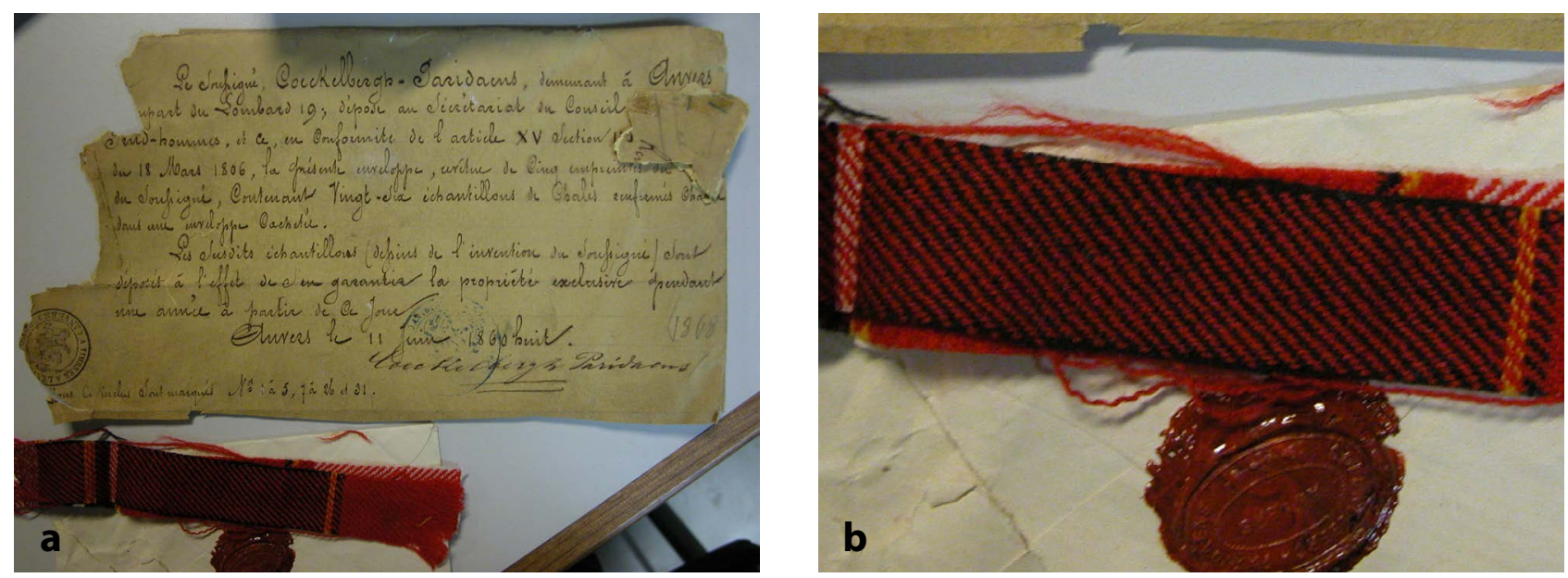

Figure 4. Industrial Tribunal: a) R540, no. 358/8/121; b) no. 1 (W37b).

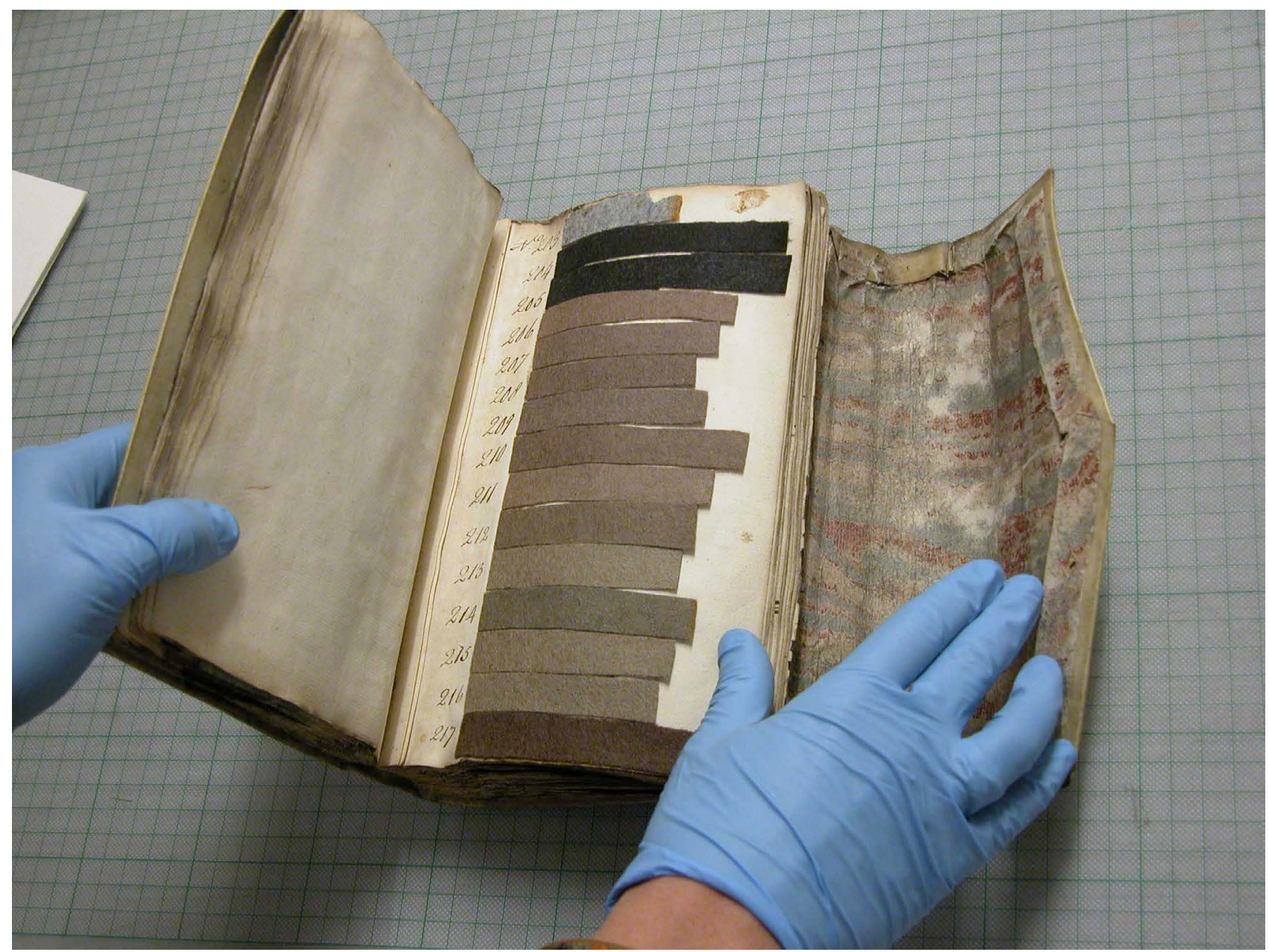

Figure 5. Sample book, TB88/122, Fashion Museum Antwerp, c.1700-1750.

distributors and the customers. No information was present about the dyeing procedure. The archive mainly consists of correspondence between Jan Michiel Melijn and commercial agents in London. Black wool samples were taken from three books. This Archive was of particular importance for the study because it is well documented and the samples enclosed have a precise frame of reference.
Antwerp City Archive, 1675-1777

In the Antwerp City Archive, different trade archives and family archives were found. Black wool samples were collected from the Insolvent inventory of De Brier - Van den Berghe - De Lannoy, from the Insolvent inventory of De Bruyne, from the family archive of Jan Frans De Wolf and from the crafts of linen weavers, passementry and 
ribbon trimmings. In case of wool and linen blends, only the black wool was taken for analysis. Figure 2 show some striped fabrics found in the craft of linen weavers.

National Archive Belgium, Antwerp section (1683-1696)

A total of five woollen samples were taken from the Belgian National Archive, Antwerp section, covering the period from 1683 until 1696. In Figure 3, thirteen woollen samples in assorted colours of the Knijff Family Archive are shown, attached to a document dated 3 September 1683. No information about dyes or fabric was found in the correspondence. Another two black samples dating from 1868 were found in the Industrial Tribunal (Sample R540, no. 358/8/121). These are woollen samples for shawls. Sample W37b is shown in Figure 4.

\section{Historical samples attributed to a certain period}

Fifteen samples attributed to a certain period were found in anonymous sample books. These samples have a broader dating as there is no correspondence attached to them. It concerns six samples found in two anonymous sample books from the Fashion Museum Antwerp (17001840) and nine samples from two anonymous sample books found in the Municipal Museum Lokeren (18701890).

Anonymous sample books, Fashion Museum Antwerp, 1700-1840

One of the sample books is a syllabus of a course concerning mainly jacquard weaving. Most of the samples are silk, although four woollen samples were found. Another sample book (Figure 5) was found with mainly woollen samples from which two black samples were taken.

Anonymous Archive Municipal Museum Lokeren, C. 1870-1890

These books are dated stylistically c. 1870-1890 (Figure 6). Most of the samples are tartan wool dyed in different colours, from which nine black samples were taken.

\section{Historical artefacts}

The historical artefacts were not attached to writings. Samples were dated stylistically in consultation with experts in this field [38]. Four historical artefacts were found in the Convent of the Women Apostles in Antwerp: two black widow's bonnets, two pieces of black cloth (once intended to be made into a bonnet), a coif and a shirt. The seventeenth-century black wool Widow's Bonnet was

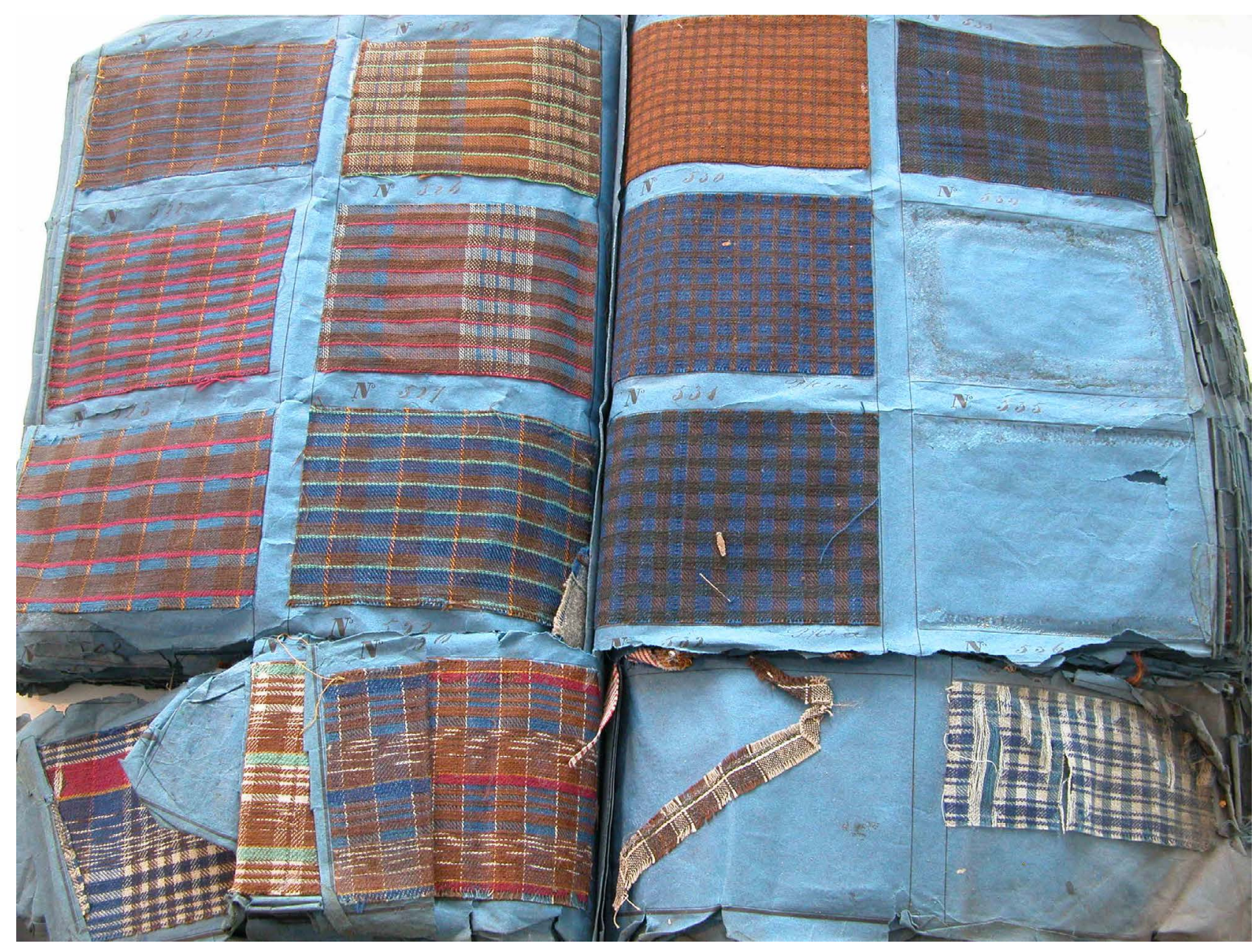

Figure 6. Book II, 533, (W77), 1870-1890. 

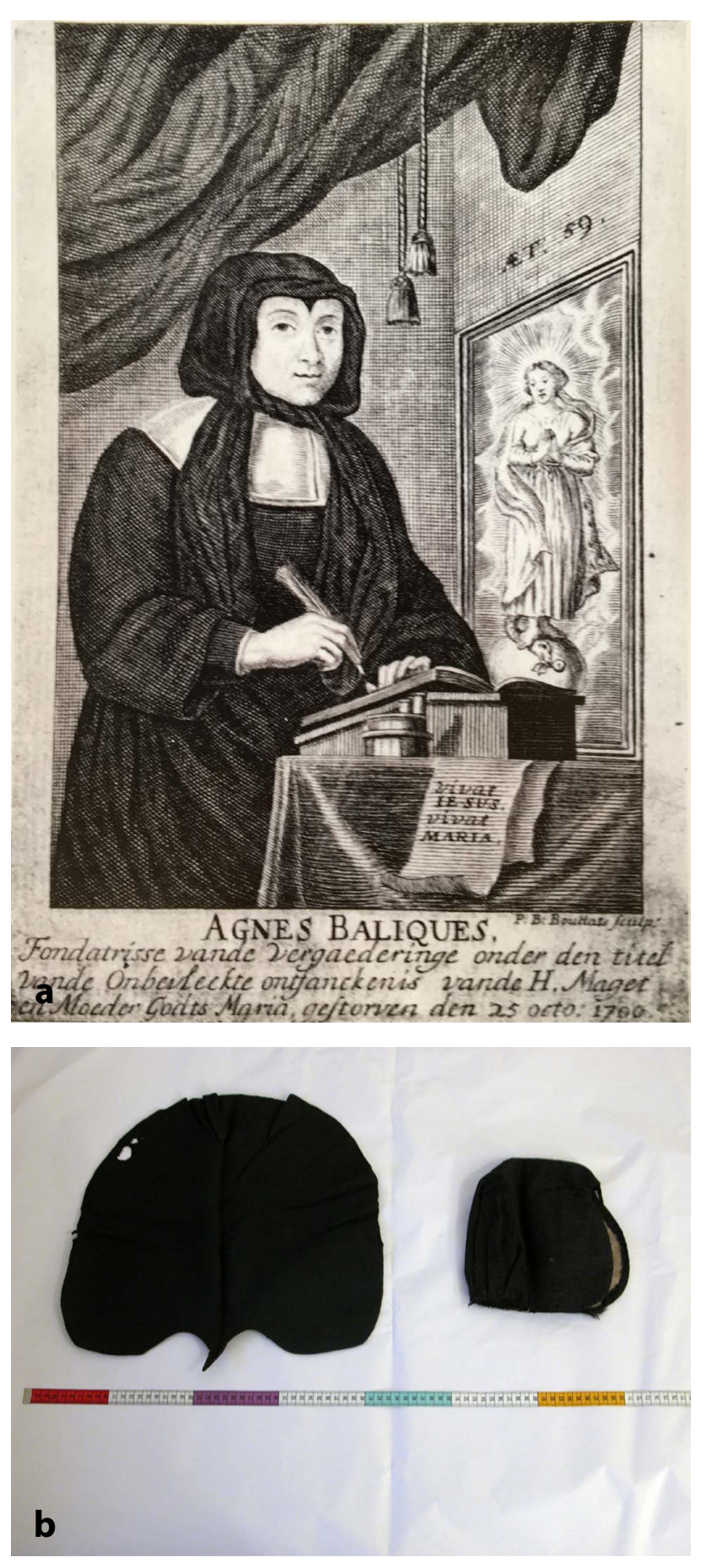

Figure 7. a) Engraving by P. B. Bouttats, Agnes Baliques, founder of the congregation of the Sisters Apostelinnen, Antwerp, first quarter eighteenth century. b) Black bonnet.

most likely originally owned by Agnes Baliques (16411700), born in Antwerp and founder of the Convent of the Women Apostles (Klooster van de Apostelinnen - now located on the Diksmuidelaan in Deurne). The surviving bonnet is a unique item and a precious historical example of a black dyed artefact from the Southern Netherlands. The bonnet is dated to the last quarter of the seventeenth century (Figure 7) and also stylistically matches to the seventeenth-century fashion [39, p. 66].

\section{Methods}

High performance liquid chromatography with photodiode array detection (HPLC-PDA)

Prior to chemical analysis, each yarn sample (sample size between 5 to $10 \mathrm{~mm}$ ) was examined using an optical stereomicroscope under reflected illumination (Stemi stereomicroscope, Zeiss) for fibre characterisation and for elimination of possible contaminants. Dye extraction was executed after immersing the sample in $250 \mu \mathrm{l}$ of a water / methanol / $37 \%$ hydrochloric acid mixture in the volumetric ratio of $1: 1: 2(\mathrm{v} / \mathrm{v} / \mathrm{v})$, which was heated for 10 minutes at $105{ }^{\circ} \mathrm{C}$ in open Pyrex tubes in a heating block. After cooling the acid preparation, any particular matter was removed by filtering through a porous polyethylene filter. The clear filtrate was dried in a vacuum rotator and the dried residue re-dissolved in $60 \mu \mathrm{l} \mathrm{methanol/water} 1: 1(\mathrm{v} / \mathrm{v})$ mixture from which $20 \mu \mathrm{l}$ was injected for analysis [28]. The equipment consisted of an Alliance HPLC system with auto sampler, a diode array detection system (PDA model 996) and data treatment software Empower 2, all from Waters. A RP-18 column was used (Lichrosorb (VWR), $125 \mathrm{~mm} \times 4 \mathrm{~mm}$ diameter, $100 \AA$ pore diameter and 5 $\mu \mathrm{m}$ particle size) at a fixed temperature of $25^{\circ} \mathrm{C}$. The mobile phase consists of A) pure methanol (grade: for HPLC > $99.8 \%$, from Acros Organics); B) methanol / water mixture $1: 9(\mathrm{v} / \mathrm{v})$; and C) $5 \%$ phosphoric acid (85 wt $\%$ pro analisi, Acros Organics). It was used according to the following gradient programme: 0-3 minutes: isocratic $23 \mathrm{~A} / 67 \mathrm{~B} / 10 \mathrm{C}$; 3-29 minutes: linear gradient to $90 \mathrm{~A} / 0 \mathrm{~B} / 10 \mathrm{C}$; $30-35$ minutes: isocratic $23 \mathrm{~A} / 67 \mathrm{~B} / 10 \mathrm{C}$. The water used was ultrapure deionised water (Milli-Q). The dye compounds were characterised by their elution time and their UV-visible absorbance spectra, which was compared against a non-commercial internal developed database of reference spectra.

\section{Scanning electron microscope coupled to energy dispersive $X$-ray spectroscopy (SEM-EDX)}

A scanning electron microscope with energy dispersive X-ray system was used to analyse the elements possibly referring to inorganic mordants. The instrument (Jeol 6300) was equipped with a thin-window Princeton Gamma Tech energy dispersive $\mathrm{Si}(\mathrm{Li})$ detector. A fibre of $1 \mathrm{~mm}$ was taken from each black woollen fabric. The fibres were coated with a thin layer of carbon applied by a SEM sputter coater (type SC7620 Mini Sputter Coater/ Glow Discharge System, Quorum Technologies). The carbon evaporates in a vacuum and provides the fibre with a thin layer of electrically conductive carbon. X-ray spectra were collected with a $2 \mathrm{nA}$ electron beam at 20 $\mathrm{keV}$. The spectra contain X-ray emission lines for elements down to carbon; detection limits of approximately $0.1 \mathrm{wt}$ $\%$ for elements with an atomic number between 11 and 20 
are obtained. The X-ray spectra were processed with the software package AXIL, with which the peak areas and the area of the Bremstrahlung background underneath the peaks could be calculated. With the areas obtained, it was possible to calculate the peak-to-background ratio for Fe and $\mathrm{Cu}$. This approach is needed to suppress the impact of variable count rates that occurred from spectrum to spectrum. Three measurements were taken from each sample.

\section{Results}

Microscopic examination of the wool samples showed that the majority of the yarns were homogenously black dyed. Few yarn samples have a more heterogeneous composition with mostly black fibres spun together with a minor amount of red dyed fibres. This was the case for sample W26 from the Melijn Archive (book T94/189, folio 30 verso, 1712) and sample W29 (the same book on fol. 158 verso, 1714).
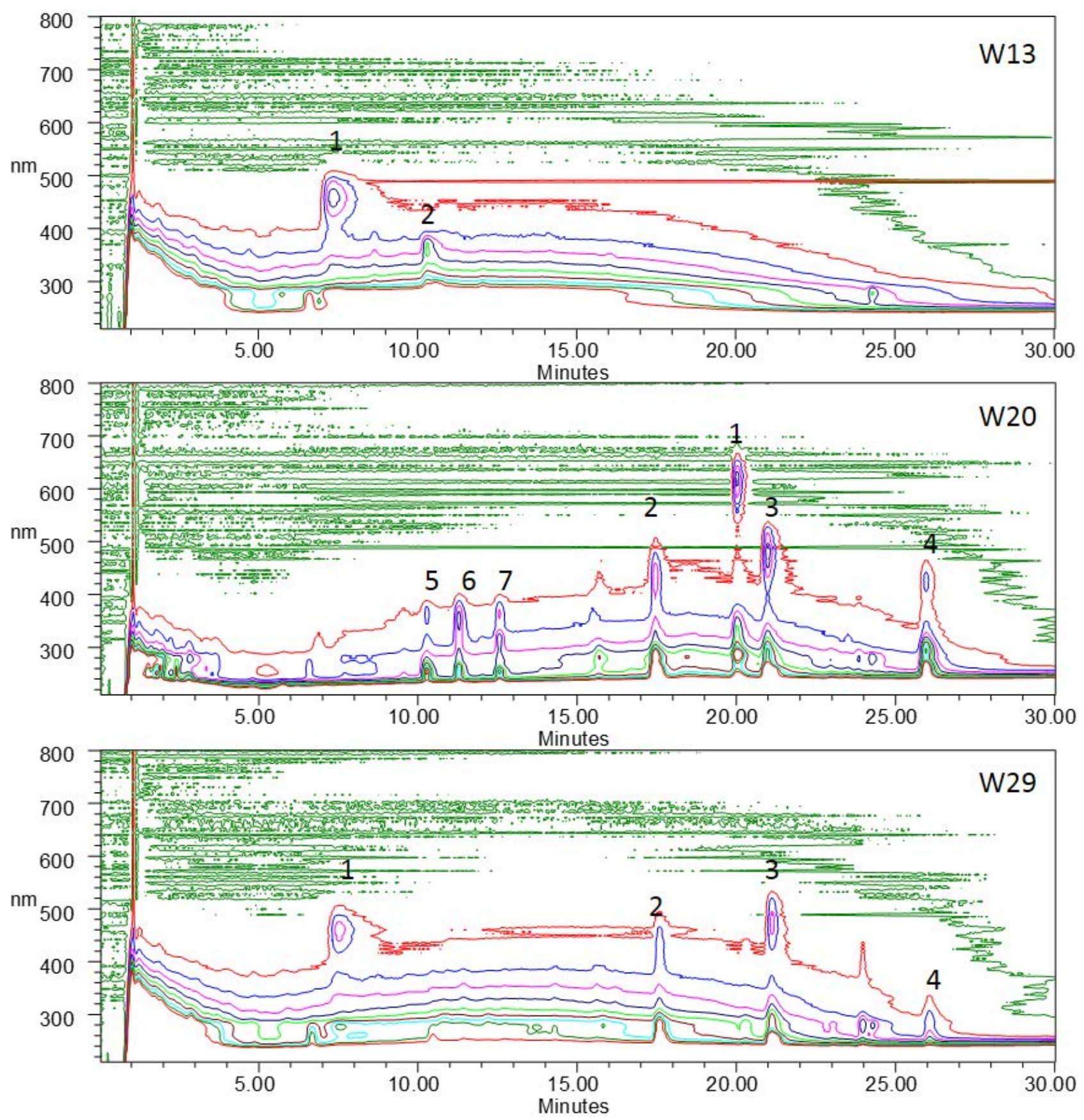

Figure 8. HPLC-DAD max-plots showing the absorbance intensities (coloured lines) of the most important molecules in function of the eluting time (x-axis) (in minutes) and absorbance spectra (y-axis) (between $240 \mathrm{~nm}$ and $800 \mathrm{~nm}$ ) of samples W13, W20 and W29, Antwerp (Archive Melijn, 1681-1714). Absorbance peak maxima are present for hematoxylin derivative (1) and ellagic acid (2) in sample W13; of indigotin (1), alizarin (2), purpurin (3), nordamnacanthal (4), ellagic acid (5), morin (6) and maclurin (7) in sample W20 and of hematoxylin derivative (1), alizarin (2), purpurin (3) and nordamnacanthal (4) in sample W29. 
Table 1

Results HPLC-PDA and SEM-EDX analyses

\begin{tabular}{|c|c|c|c|c|c|c|c|}
\hline Archive & $\begin{array}{l}\text { Book / } \\
\text { Collection }\end{array}$ & $\begin{array}{l}\text { Wool } \\
\text { code, date }\end{array}$ & $\begin{array}{l}\text { Wool } \\
\text { colour }\end{array}$ & $\begin{array}{l}\text { Main } \\
\text { organic dye } \\
\text { ingrediënts } \\
\text { (HPLC-DAD) }\end{array}$ & $\begin{array}{l}\text { Accompanying } \\
\text { organic dye } \\
\text { ingredients } \\
\text { (HPLC-DAD) }\end{array}$ & $\begin{array}{l}\text { Detected organic (dye) molecules } \\
\text { (HPLC-DAD) }\end{array}$ & $\begin{array}{l}\text { Inorganic } \\
\text { elements } \\
\text { (SEM- } \\
\text { EDX) }\end{array}$ \\
\hline \multirow{19}{*}{$\begin{array}{l}\text { Archive } \\
\text { Melijn, } \\
\text { Fashion } \\
\text { Museum } \\
\text { Antwerp, } \\
\text { 1681-1714 }\end{array}$} & \multirow{10}{*}{$\begin{array}{l}\text { Book } \\
\text { T94/183, } \\
1681- \\
1682\end{array}$} & W13, 1681 & Black & $\begin{array}{l}\text { Logwood and } \\
\text { tannin }\end{array}$ & - & Hematoxylin, ellagic acid & $\mathrm{Fe}$ \\
\hline & & W14, 1681 & Black & $\begin{array}{l}\text { Logwood and } \\
\text { tannin }\end{array}$ & Madder & Hematoxylin, ellagic acid, alizarin & $\mathrm{Fe}$ \\
\hline & & W15, 1681 & Black & $\begin{array}{l}\text { Logwood and } \\
\text { tannin }\end{array}$ & Madder & $\begin{array}{l}\text { Hematoxylin, ellagic acid, alizarin, } \\
\text { purpurin }\end{array}$ & $\mathrm{Fe}$ \\
\hline & & W16, 1681 & Dark brown & $\begin{array}{l}\text { Logwood and } \\
\text { tannin }\end{array}$ & Old fustic & Hematoxylin, ellagic acid, maclurin & $\mathrm{Fe}$ \\
\hline & & W17, 1681 & Grey-Black & $\begin{array}{l}\text { Logwood and } \\
\text { tannin }\end{array}$ & $\begin{array}{l}\text { Indigo/woad } \\
\text { and madder }\end{array}$ & $\begin{array}{l}\text { Hematoxylin, ellagic acid, alizarin, } \\
\text { indigotin }\end{array}$ & $\mathrm{Fe}$ \\
\hline & & W18, 1682 & Black & $\begin{array}{l}\text { Logwood and } \\
\text { tannin }\end{array}$ & - & Hematoxylin, ellagic acid & $\mathrm{Fe}$ \\
\hline & & W19a, 1682 & Black & $\begin{array}{l}\text { Logwood and } \\
\text { tannin }\end{array}$ & Madder & $\begin{array}{l}\text { Hematoxylin, ellagic acid, alizarin, } \\
\text { purpurin, xanthopurpurin }\end{array}$ & $\mathrm{Fe}$ \\
\hline & & W19b, 1682 & Black & $\begin{array}{l}\text { Logwood and } \\
\text { tannin }\end{array}$ & - & Hematoxylin, ellagic acid & $\mathrm{Fe}, \mathrm{Al}$ \\
\hline & & W19c, 1682 & Black & $\begin{array}{l}\text { Logwood and } \\
\text { tannin }\end{array}$ & - & Hematoxylin, ellagic acid & $\mathrm{Fe}$ \\
\hline & & W10, 1692 & Dark brown & $\begin{array}{l}\text { Tannin and } \\
\text { madder }\end{array}$ & $\begin{array}{l}\text { Old fustic } \\
\text { and dyer's } \\
\text { greenweed }\end{array}$ & $\begin{array}{l}\text { Ellagic acid, genistein, luteolin, } \\
\text { apigenin, alizarin, purpurin, } \\
\text { nordamnacanthal, maclurin, morin, } \\
\text { anthragallol, xanthopurpurin }\end{array}$ & $\mathrm{Fe}$ \\
\hline & \multirow[t]{4}{*}{$\begin{array}{l}\text { Book } \\
\text { T94/187, } \\
1695\end{array}$} & W20, 1695 & $\begin{array}{l}\text { Rred-black } \\
\& \text { blue }\end{array}$ & $\begin{array}{l}\text { Indigo/woad } \\
\text { and madder }\end{array}$ & $\begin{array}{l}\text { Tannin and old } \\
\text { fustic }\end{array}$ & $\begin{array}{l}\text { Indigotin, alizarin, purpurin, } \\
\text { morin, maclurin, nordamnacanthal, } \\
\text { ellagic acid, anthragallol, rubiadin, } \\
\text { kampferol, munjistin }\end{array}$ & $\mathrm{Fe}$ \\
\hline & & W21, 1696 & $\begin{array}{l}\text { Red-black \& } \\
\text { blue }\end{array}$ & $\begin{array}{l}\text { Indigo/woad } \\
\text { and madder }\end{array}$ & $\begin{array}{l}\text { Tannin and old } \\
\text { fustic }\end{array}$ & $\begin{array}{l}\text { Indigotin, alizarin, purpurin, morin, } \\
\text { maclurin, nordamnacanthal, ellagic } \\
\text { acid, anthragallol, rubiadin, munjistin }\end{array}$ & $\mathrm{Fe}$ \\
\hline & & W24, 1695 & Brown-black & $\begin{array}{l}\text { Indigo/woad } \\
\text { and madder }\end{array}$ & $\begin{array}{l}\text { Tannin, } \\
\text { old fustic } \\
\text { and dyer's } \\
\text { greenweed }\end{array}$ & $\begin{array}{l}\text { Indigotin, ellagic acid, morin, } \\
\text { maclurin, genistein, luteolin, } \\
\text { apigenin, alizarin, purpurin, } \\
\text { nordamnacanthal, rubiadin }\end{array}$ & $\mathrm{Fe}$ \\
\hline & & W25, 1696 & Brown-black & $\begin{array}{l}\text { Indigo/woad } \\
\text { and madder }\end{array}$ & $\begin{array}{l}\text { Tannin and old } \\
\text { fustic }\end{array}$ & $\begin{array}{l}\text { Indigotin, alizarin, purpurin, } \\
\text { morin, maclurin, nordamnacanthal, } \\
\text { ellagic acid, anthragallol, rubiadin, } \\
\text { munjistin }\end{array}$ & - \\
\hline & \multirow[t]{5}{*}{$\begin{array}{l}\text { Book } \\
\text { T94/189, } \\
1712- \\
1714\end{array}$} & W26, 1712 & Red-brown & $\begin{array}{l}\text { Logwood and } \\
\text { madder }\end{array}$ & Tannin & $\begin{array}{l}\text { Alizarin, purpurin, } \\
\text { nordamnacanthal, ellagic } \\
\text { acid, hematoxylin, rubiadin, } \\
\text { xanthopurpurin }\end{array}$ & $\mathrm{Fe}$ \\
\hline & & W27, 1713 & Black & $\begin{array}{l}\text { Logwood and } \\
\text { tannin }\end{array}$ & $\begin{array}{l}\text { Old fustic and } \\
\text { weld }\end{array}$ & $\begin{array}{l}\text { Ellagic acid, hematoxylin, quercetin, } \\
\text { luteolin, kampferol, apigenin }\end{array}$ & $\mathrm{Fe}$ \\
\hline & & W28a,1713 & Black & $\begin{array}{l}\text { Logwood and } \\
\text { madder }\end{array}$ & $\begin{array}{l}\text { Tannin, old } \\
\text { fustic and weld }\end{array}$ & $\begin{array}{l}\text { Alizarin, purpurin, hematoxylin, } \\
\text { ellagic acid, maclurin, kampferol, } \\
\text { luteolin, rubiadin, xanthopurpurin }\end{array}$ & $\mathrm{Fe}$ \\
\hline & & W28b, 1713 & Black & $\begin{array}{l}\text { Logwood and } \\
\text { madder }\end{array}$ & $\begin{array}{l}\text { Tannin and old } \\
\text { fustic }\end{array}$ & $\begin{array}{l}\text { Alizarin, purpurin, hematoxylin, } \\
\text { ellagic acid, morin, maclurin, } \\
\text { kampferol, rubiadin, xanthopurpurin }\end{array}$ & $\mathrm{Fe}$ \\
\hline & & W29, 1714 & Red-black & $\begin{array}{l}\text { Logwood and } \\
\text { madder }\end{array}$ & $\begin{array}{l}\text { Tannin, old } \\
\text { fustic and weld }\end{array}$ & $\begin{array}{l}\text { Alizarin, purpurin, } \\
\text { nordamnacanthal, hematoxylin, } \\
\text { ellagic acid, rubiadin, } \\
\text { xanthopurpurin, maclurin, luteolin, } \\
\text { kampferol, apigenin, anthragallol }\end{array}$ & $\mathrm{Fe}$ \\
\hline
\end{tabular}




\section{Table 1 (continued)}

\begin{tabular}{|c|c|c|c|c|c|c|c|}
\hline Archive & $\begin{array}{l}\text { Book/ } \\
\text { Collection }\end{array}$ & $\begin{array}{l}\text { Wool } \\
\text { code, date }\end{array}$ & $\begin{array}{l}\text { Wool } \\
\text { colour }\end{array}$ & $\begin{array}{l}\text { Main } \\
\text { organic dye } \\
\text { ingrediënts } \\
\text { (HPLC-DAD) }\end{array}$ & $\begin{array}{l}\text { Accompanying } \\
\text { organic dye } \\
\text { ingredients } \\
\text { (HPLC-DAD) }\end{array}$ & $\begin{array}{l}\text { Detected organic (dye) molecules } \\
\text { (HPLC-DAD) }\end{array}$ & $\begin{array}{l}\text { Inorganic } \\
\text { elements } \\
\text { (SEM- } \\
\text { EDX) }\end{array}$ \\
\hline \multirow{11}{*}{$\begin{array}{l}\text { City } \\
\text { Archive } \\
\text { Antwerp, } \\
1675-1777\end{array}$} & \multirow{5}{*}{ 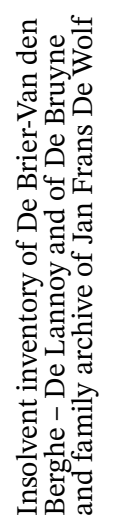 } & $\begin{array}{l}\text { W32, } 1675- \\
1725\end{array}$ & Black & Tannin & Young fustic & Ellagic acid, sulfuretin & $\mathrm{Fe}, \mathrm{Al}$ \\
\hline & & $\begin{array}{l}\text { W34, 1675- } \\
1725\end{array}$ & Black & Tannin & $\begin{array}{l}\text { Old fustic and } \\
\text { weld }\end{array}$ & $\begin{array}{l}\text { Ellagic acid, quercetin, luteolin, } \\
\text { kampferol }\end{array}$ & $\mathrm{Fe}, \mathrm{Cu}, \mathrm{Al}$ \\
\hline & & W68, 1771 & Black & $\begin{array}{l}\text { Tannin and } \\
\text { madder }\end{array}$ & $\begin{array}{l}\text { Brazilwood } \\
\text { and weld }\end{array}$ & $\begin{array}{l}\text { Alizarin, purpurin, ellagic acid, } \\
\text { urolithine C, luteolin, kampferol, } \\
\text { apigenin, xanthopurpurin, } \\
\text { munjistin }\end{array}$ & $\mathrm{Fe}$ \\
\hline & & W68a, 1771 & Black & $\begin{array}{l}\text { Logwood and } \\
\text { madder }\end{array}$ & Indigo/woad & $\begin{array}{l}\text { Alizarin, purpurin, hematoxylin, } \\
\text { indigotin }\end{array}$ & $\mathrm{Fe}$ \\
\hline & & W69, 1777 & Brown-Black & $\begin{array}{l}\text { Tannin and } \\
\text { sandalwood }\end{array}$ & - & Ellagic acid, santalin & $\mathrm{Fe}, \mathrm{Al}$ \\
\hline & \multirow{6}{*}{ 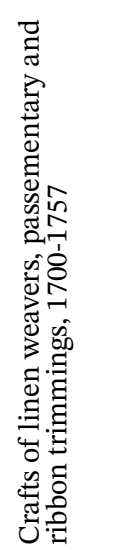 } & & & & & & \\
\hline & & W35, 1757 & Black & Logwood & - & Hematoxylin & $\mathrm{Fe}, \mathrm{Cu}$ \\
\hline & & W35a, 1757 & Black & $\begin{array}{l}\text { Tannin, } \\
\text { madder and } \\
\text { logwood }\end{array}$ & Weld & $\begin{array}{l}\text { Ellagic acid, hematoxylin, alizarin, } \\
\text { purpurin, luteolin, apigenin, } \\
\text { nordamnacanthal, xanthopurpurin, } \\
\text { rubiadin }\end{array}$ & $\mathrm{Fe}, \mathrm{Cu}$ \\
\hline & & W35b, 1757 & Black & Logwood & - & Hematoxylin & $\mathrm{Fe}, \mathrm{Cu}$ \\
\hline & & $\begin{array}{l}\text { W36, 1700- } \\
1775\end{array}$ & Black & Tannin & Old fustic & Ellagic acid, kampferol & $\mathrm{Fe}$ \\
\hline & & W60, 1757 & Black & $\begin{array}{l}\text { Logwood, } \\
\text { tannin and } \\
\text { weld }\end{array}$ & - & $\begin{array}{l}\text { Ellagic acid, hematoxylin, luteolin, } \\
\text { apigenin }\end{array}$ & $\mathrm{Fe}$ \\
\hline \multirow{5}{*}{$\begin{array}{l}\text { Belgium } \\
\text { National } \\
\text { Archive, } \\
\text { 1683-1696 }\end{array}$} & \multirow{2}{*}{$\begin{array}{l}\text { Industrial } \\
\text { Tribunal, } \\
1868\end{array}$} & W37b, 1868 & Black & Logwood & - & Hematoxylin & $\mathrm{Fe}$ \\
\hline & & W37, 1868 & Black & Logwood & - & Hematoxylin & $\mathrm{Fe}$ \\
\hline & \multirow{3}{*}{$\begin{array}{l}\text { Family } \\
\text { Archives } \\
\text { Knijff } \\
1683- \\
1696\end{array}$} & W92, 1683 & $\begin{array}{l}\text { Brownish } \\
\text { Black }\end{array}$ & Tannin & $\begin{array}{l}\text { Dyer's } \\
\text { greenweed }\end{array}$ & Ellagic acid & $\mathrm{Fe}$ \\
\hline & & W38, 1696 & Black & $\begin{array}{l}\text { Logwood, } \\
\text { tannin and } \\
\text { madder }\end{array}$ & - & $\begin{array}{l}\text { Hematoxylin, ellagic acid, } \\
\text { alizarin, purpurin, antragallol, } \\
\text { xanthopurpurin, rubiadin }\end{array}$ & $\mathrm{Fe}$ \\
\hline & & W38a, 1696 & $\begin{array}{l}\text { Brownish } \\
\text { Black }\end{array}$ & $\begin{array}{l}\text { Tannin and } \\
\text { brazilwood }\end{array}$ & Old fustic & Ellagic acid, urolithine C, sulfuretin & $\mathrm{Fe}$ \\
\hline \multirow[t]{4}{*}{$\begin{array}{l}\text { Anonymous } \\
\text { sample } \\
\text { books } \\
\text { Fashion } \\
\text { Museum } \\
\text { Antwerp }\end{array}$} & \multirow[t]{2}{*}{$\begin{array}{l}\text { Book } \\
\text { TB88 } \\
/ 122, \\
1700- \\
1750\end{array}$} & W30 & Black & $\begin{array}{l}\text { Logwood, } \\
\text { tannin, } \\
\text { indigo/ } \\
\text { woad and } \\
\text { brazilwood }\end{array}$ & $\begin{array}{l}\text { Madder and } \\
\text { weld }\end{array}$ & $\begin{array}{l}\text { Hematoxylin, ellagic acid, indigotin, } \\
\text { luteolin, urolithine } \mathrm{C} \text {, apigenin, } \\
\text { alizarin }\end{array}$ & - \\
\hline & & W31 & Black & $\begin{array}{l}\text { Logwood and } \\
\text { indigo/woad }\end{array}$ & $\begin{array}{l}\text { Old fustic and } \\
\text { weld }\end{array}$ & $\begin{array}{l}\text { Hematoxylin, indigotin, maclurin, } \\
\text { quercetin, luteolin, kampferol, } \\
\text { apigenin }\end{array}$ & $\mathrm{Fe}$ \\
\hline & \multirow[t]{2}{*}{$\begin{array}{l}\text { Book } \\
\text { T99/103, } \\
1820- \\
1840\end{array}$} & W59, 1822 & Black & $\begin{array}{l}\text { Logwood } \\
\text { and dyer's } \\
\text { greenweed }\end{array}$ & Tannin & $\begin{array}{l}\text { Hematoxylin, ellagic acid, genistein, } \\
\text { luteolin, apigenin }\end{array}$ & - \\
\hline & & $\begin{array}{l}\text { WT99 / } \\
103 \text { A,B } \\
1820-1840\end{array}$ & Red-black & $\begin{array}{l}\text { Logwood and } \\
\text { tannin }\end{array}$ & $\begin{array}{l}\text { Cochineal, } \\
\text { brazilwood } \\
\text { and old fustic, } \\
\text { indigo/woad }\end{array}$ & $\begin{array}{l}\text { Hematoxylin, ellagic acid, } \\
\text { urolithine } C \text {, maclurin, carminic } \\
\text { acid, indigotin }\end{array}$ & $\mathrm{Fe}, \mathrm{Cu}, \mathrm{Al}$ \\
\hline
\end{tabular}


Table 1 (continued)

\begin{tabular}{|c|c|c|c|c|c|c|c|}
\hline Archive & $\begin{array}{l}\text { Book/ } \\
\text { Collection }\end{array}$ & $\begin{array}{l}\text { Wool } \\
\text { code, date }\end{array}$ & $\begin{array}{l}\text { Wool } \\
\text { colour }\end{array}$ & $\begin{array}{l}\text { Main } \\
\text { organic dye } \\
\text { ingrediënts } \\
\text { (HPLC-DAD) }\end{array}$ & $\begin{array}{l}\text { Accompanying } \\
\text { organic dye } \\
\text { ingredients } \\
\text { (HPLC-DAD) }\end{array}$ & $\begin{array}{l}\text { Detected organic (dye) molecules } \\
\text { (HPLC-DAD) }\end{array}$ & $\begin{array}{l}\text { Inorganic } \\
\text { elements } \\
\text { (SEM- } \\
\text { EDX) }\end{array}$ \\
\hline \multirow{9}{*}{$\begin{array}{l}\text { Anonymous } \\
\text { Archive, } \\
\text { Municipal } \\
\text { Museum, } \\
\text { Lokeren, } \\
\text { 1870-1890 }\end{array}$} & \multirow{4}{*}{$\begin{array}{l}\text { Book I, } \\
1870- \\
1890\end{array}$} & W70 & Black & Logwood & - & Hematoxylin & $\mathrm{Fe}, \mathrm{Cu}$ \\
\hline & & W71 & Black & Logwood & Brazilwood & Hematoxylin, urolithine C & $\mathrm{Fe}, \mathrm{Cu}$ \\
\hline & & W72 & Black & $\begin{array}{l}\text { Logwood and } \\
\text { tannin }\end{array}$ & - & Hematoxylin, ellagic acid & $\mathrm{Fe}, \mathrm{Cu}$ \\
\hline & & W73 & Black & Logwood & - & Hematoxylin & $\mathrm{Fe}, \mathrm{Cu}, \mathrm{Al}$ \\
\hline & \multirow{5}{*}{$\begin{array}{l}\text { Book II, } \\
1870- \\
1890\end{array}$} & W74 & brown-Black & Logwood & $\begin{array}{l}\text { Indigo/woad } \\
\text { and madder }\end{array}$ & Hematoxylin, alizarin, indigotin & $\mathrm{Fe}, \mathrm{Cu}$ \\
\hline & & W75 & Black & $\begin{array}{l}\text { Logwood and } \\
\text { indigo/woad }\end{array}$ & Old fustic & $\begin{array}{l}\text { Hematoxylin, maclurin, indigotin, } \\
\text { indirubin }\end{array}$ & $\mathrm{Fe}, \mathrm{Cu}$ \\
\hline & & W76 & brown-Black & Logwood & - & Hematoxylin & - \\
\hline & & W77 & Black & $\begin{array}{l}\text { Indigo/woad } \\
\text { and tannin }\end{array}$ & - & Ellagic acid, indigotin, indirubin & $\mathrm{Fe}, \mathrm{Cu}$ \\
\hline & & W78 & Black & $\begin{array}{l}\text { Logwood and } \\
\text { indigo/woad }\end{array}$ & - & Hematoxylin, indigotin & - \\
\hline \multirow{4}{*}{$\begin{array}{l}\text { Historical } \\
\text { Artefacts: } \\
\text { textiles } \\
\text { attributed } \\
\text { to Agnes } \\
\text { Baliques, } \\
1675-1700\end{array}$} & & W79 & Black & $\begin{array}{l}\text { Tannin and } \\
\text { indigo/woad }\end{array}$ & - & Ellagic acid, indigotin & $\mathrm{Fe}$ \\
\hline & & W80 & Black & $\begin{array}{l}\text { Tannin and } \\
\text { logwood }\end{array}$ & - & Hematoxylin, ellagic acid & $\mathrm{Fe}$ \\
\hline & & W81 & Black & Logwood & - & Hematoxylin & $\mathrm{Fe}$ \\
\hline & & W82 & Black & Logwood & - & Hematoxylin & $\mathrm{Fe}, \mathrm{Cu}$ \\
\hline
\end{tabular}

The results of the chromatographic and elemental analysis of the historical wool samples are summarized for each archive and for the historical artefacts in Table 1. The code and currently observed colour of the samples are mentioned in the first two columns, while column 5 describes the organic dye and dye marker molecules detected after HPLC-DAD analysis of the dye extracts. The corresponding biological dye sources (plant or animal) are given in columns 3 and 4. In an attempt to link the identified organic dye ingredients to the likely dyeing processes used, a distinction was made between the most important and the less important, or accompanying dye ingredients for each black dyeing, based on the relative intensities of the peak areas of the different molecules. The main dye ingredient(s) for each black dyeing is listed in column 3, the less prominent dye source(s) in column 4. When multiple dye molecules were prominently present, they were all considered as main ingredients.

Three examples are given in Figure 8 to show how the attribution between main and accompanying dye sources was made with the help of the HPLC max-plots, which give the absorbance intensity of each chemical compound (coloured lines) as function of the eluting time (x-axis) and absorbance spectra (y-axis) of samples W13, W20 and W29. A systematic description of all detected dye compounds and related dye sources is given bellow.
Logwood and tannin were defined as main ingredients of sample W13 based on the detection of a derivative of hematoxylin and ellagic acid. No accompanying ingredients were used. The main ingredients found in sample W20 are indigo/woad and madder, based on the detection of prominent peaks of indigotin and alizarin, purpurin and nordamnacanthal. Tannin and old fustic are considered as accompanying ingredients due to the less prominent intensity of the compounds ellagic acid, morin and maclurin. It must be noted that not all the detected components can be seen on the max-plot. Logwood and madder are the main ingredients of W29, based on the major peaks of alizarin, purpurin and the derivative of hematoxylin, while tannin, old fustic and weld are considered as minor ingredients, due to the low intensity of the compounds ellagic acid, maclurin, kampferol, luteolin, apigenin (hardly detectable on the max-plot).

Elements detected with SEM-EDX are presented in the last column of Table 1. Iron, copper and aluminium are three elements frequently detected although with a low signal. As these elements are common contaminants present in water, dust and dirt, their presence does not imply the use of metal mordants and, for this reason, cannot be interpreted as a possible reference to mordants. Only detection of elements with a mean normalised $\mathrm{K}$-alpha peak of, at least, 0.05 are listed in Table 1. 
For all samples where iron and copper were measured, the ratio between the detected iron (normalised Fe $\mathrm{K}$-alpha peak) and copper (normalised $\mathrm{Cu} \mathrm{K}$-alpha peak) is presented in Figure 9. Four groups are distinguished according to the date of the samples. Iron is detected in various amounts in all samples throughout the whole period of 1650-1890. However, the use of an iron based mordant with a higher content of copper seems not to occur before 1720, while becoming more popular in the eighteenth and nineteenth century (in the 1720-1820 and 1850-1890). A linear relationship between the copper and iron peak signals was observed for a few samples from the 1720-1820 period (blue dots), which might be an indication of the use of a similar mordant with higher copper content in these samples. This linear relation does not apply, however, for the samples dated from the later period of 18501890 (yellow dots). More analyses of historical samples are required to confirm these observations.

\section{Discussion on the ingredients and techniques}

\section{Organic dye ingredients}

Tannin

Ellagic acid is a marker compound which refers to the presence of ellagi- or gallotannins, polyphenolic secondary metabolites of higher plants [19, pp. 691694], also known as hydrolysable tannins. This organic molecule was identified in thirty-nine samples, few times in combination with gallic acid. Tannins are present in various parts of the structure of numerous plant species geographically distributed all over the world. Since prehistoric times, they were used as mordant and/ or dyeing ingredient for textiles. The fact that often only ellagic acid is detected in the extracts of historical textiles after acidic hydrolysis makes it impossible so far to identify the exact plant species [19, pp. 409-484]. Therefore, this ingredient is mentioned in the result table as tannin. From the historical recipe sources, on the other hand, it is clear that gallnuts from the gall oak (Quercus infectoria L.) or sumac (Rhus species.) are among the most probable sources [1, p. 287; 19, pp. 414-415].

\section{Indigo and/or woad (vat dyes)}

Fourteen samples were found containing indigotin, the major dye molecule referring to a vat dyeing with indigo (Indigofera or Polygonum species) or with woad (Isatis tinctoria L.). In a few samples, the minor compound indirubin was also detected. As both indigotin and indirubin are the marker compound found in the extracts of fibres dyed with indigo species or woad, no distinction can be made between the two. Therefore, they are always mentioned together. In seventeenth-century Europe however, indigo was used more frequently than woad [19, p. 214].

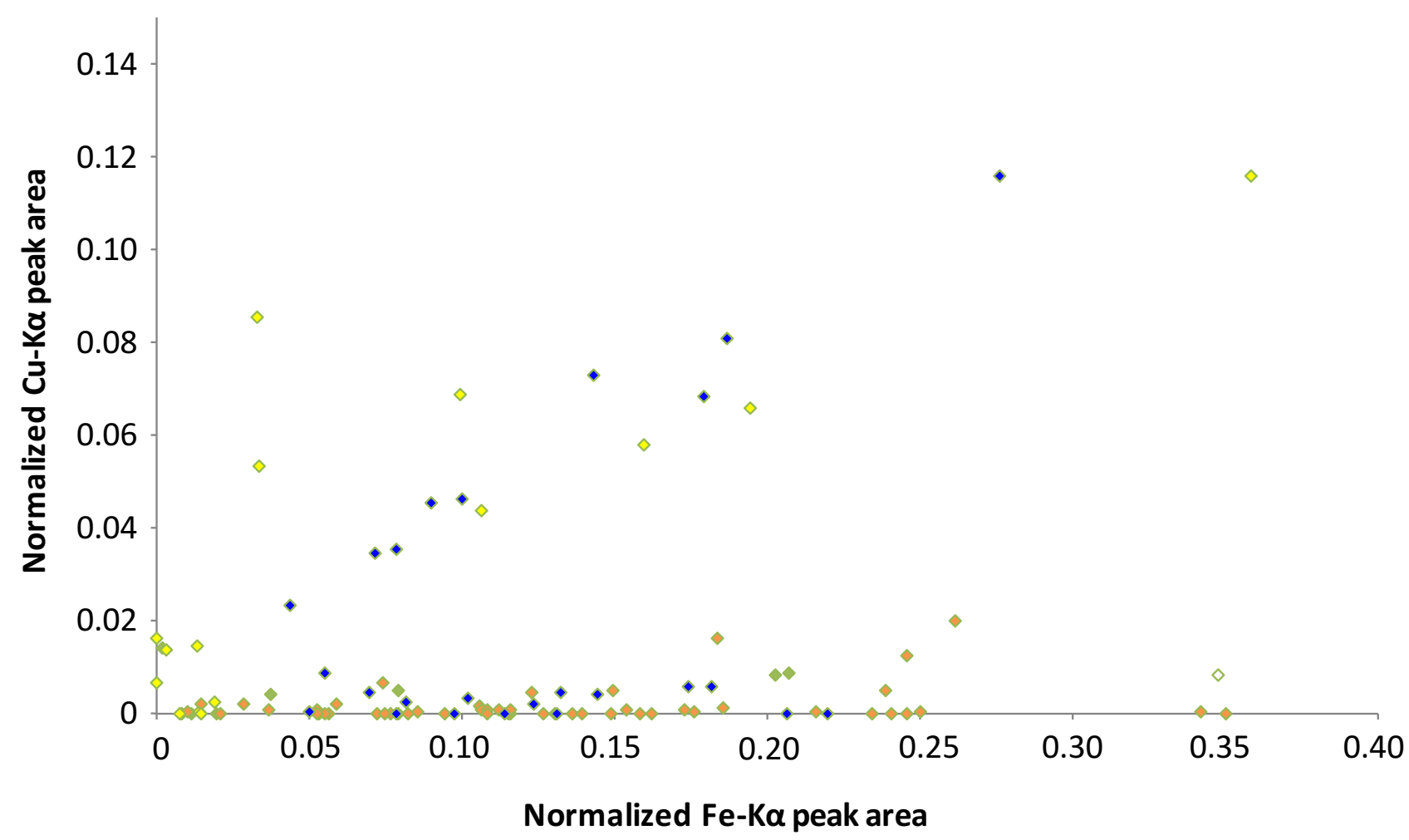

Figure 9. Element analyses of the wool samples from 1650-1850 (three measurements per sample): orange represent the 1650-1720 period, blue represent the 1720-1820 period, green represent the 1820-1850 period and yellow represent the 1850-1890 period. 


\section{Logwood}

A derivative of hematoxylin was detected in thirty-nine of the fifty-one samples. It is a compound obtained by the acidic hydrolysis step used by one of the authors, in a previous paper [21], to recover the dyes from the fibres. Hematoxylin is a flavonoid molecule, the major dye molecule of logwood (Haematoxylum campechianum L.). This mordant dye became a very important ingredient for dyeing wool black in the seventeenth century. Its enormous popularity, rising from that moment up to the nineteenth-century, was based on technical advancements in the dyeing process, resulting in a much stable black dyeing with logwood, as well as on the rising importance of black clothing in nineteenth-century fashion [19, pp. 263-274].

\section{Soluble redwood (sappan- or brazilwood)}

Soluble redwood (Caesalpinia species), with brazilin as main dye molecule, was identified in five samples, based on the detection of urolithine $\mathrm{C}$, a marker compound of any soluble redwood such as sappan- or brazilwood [40]. Redwoods were used to economise on the expensive madder [19, pp. 27, 42, 89; 22, p. 516].

\section{Insoluble redwood (sandalwood)}

In one sample, a santalin compound was detected, referring to the use of an insoluble redwood, such as red sandalwood (Pterocarpus species) [19, pp. 290-299].

\section{Madder roots}

The red anthraquinone dye compounds alizarin and purpurin are the main dye molecules indicative for dyeing with the roots of madder (Rubia tinctorum L.). In multiple samples, they were detected in the presence of minor dye molecules nordamnacanthal, rubiadin, xanthopurpurin, munjistin and anthragallol. Red mordant dyes from madder were identified in eighteen samples; in three of them in very small amounts.

\section{Mexican cochineal}

Evidence for the use of the scale insect red Mexican cochineal (Dactylopius coccus Costa) in the black wool samples was found only twice and in minor quantities. It was identified based on the detection of the dye molecule carminic acid. Porphyrophora scale insects such as Polish (P. polonica L.) and Armenian cochineal (P. hamelii Brandt) species also have carminic acid as their main dye molecule [41-42], but these species can be almost completely excluded on the basis of the nineteenth century context of the samples in which they were detected.

\section{Luteolin-based yellow plant sources}

Luteolin and apigenin are the main dye molecules from yellow dye plants such as weld (Reseda luteola L.), sawwort (Serratula tinctoria L.), chamomile (Anthemis species) and many other luteolin based yellow dye sources. In the presence of genistein as third marker molecule, the plant can be specified as dyer's greenweed (Genista tinctoria L.), while chrysoeriol as third dye compound is indicative for weld. Dyer's greenweed was found to be used in twelve samples [19, pp. 168-181].

\section{Yellow dye woods (old and young fustic)}

Dyes from the yellow dye plant old fustic, also known as dyer's mulberry (Chlorophora tinctoria L.), were detected in fifteen samples, based on the identification of the benzophenone compound maclurin and the flavonoid dye compound morin together, in some samples, with kampferol and quercetin. Only one sample showed the use of the yellow dye plant known as young fustic (Cotinus coggygria L.), out of the detection of the flavonoid molecules fisetin and sulfuretin [19, pp. 191-199].

\section{Dye ingredients found in the well- dated historical textiles}

Melijn Archive, Antwerp (1681-1714)

Although covering a narrow period of 33 years, the HPLC analyses show that the nature of black dyeing in most samples differs between the three archival books (Table 1). According to literature sources, dyers were allowed to dye a blue undertone with logwood during that period, followed by an overdyeing with tannin in combination of iron sulphates or acetates [22, p. 558]. When comparing and analysing the results, it is evident that many recipes with a combination of at least two to five organic ingredients were used to obtain the black colour. The detection of iron in most of the samples could indicate the use of iron salts.

In Book T94/183 (1681-1682), the main organic dye ingredients in nine out of ten samples are logwood and tannin. Apart from the main ingredients, different accompanying dyes were identified: red dyes from madder, yellow dyes from old fustic and blue dyes from indigo/woad. The analyses confirm a ground-dyeing with logwood, after which a nice black was obtained by the addition of tannins, red and yellow dyes, and most probably iron salts. The only dark brown coloured sample (W10) was also the only one not dyed with logwood, but by a combination of tannin and madder as main dye sources accompanied by yellow dyes from dyer's greenweed and old fustic.

The dark samples from the second Book T94/187 (1695) do not have logwood but indigo/woad and madder as the main dye ingredients, while tannin and yellow dyes from old fustic and dyers' greenweed are used as minor dyes, conceivably combined with iron salts. The main components detected in most of the samples of the third Book T94/189 (1712-1714) are logwood and madder. 
Tannins are present, though not used as major dye source. Yellow dyes from old fustic and weld (or an equivalent luteolin-based dye source, see above) are found as minor ingredients, again perhaps combined with iron salts. Sample W27 is the only sample from this book dyed with logwood and tannin as the main biological sources, in the presence of weld, old fustic and an iron mordant - hence, according to a similar black dye procedure as applied in the samples of the first book T94/183.

The red dyes are dominant in the black samples from the last two books. Although the samples look black at first sight, it is very likely that these samples were dyed very deep brown.

The Insolvent Inventory from the City of Antwerp (1675-1777) comprises samples of black cloth and multicoloured striped woollen fabrics from which the black yarns where analysed (Table 1). The dye analyses showed that there is a distinction between the dyeing procedures for the two types of yarns. Madder is the main ingredient of the black yarns from the striped fabrics (samples W68, W68a), while tannins forms the main biological source in the black fabrics (samples W32, W34 and W69).

In sample W68a from the first group, madder was applied on a blue undertone made with logwood and indigo/woad as minor ingredients, while sample W68 has both madder and tannin as main, and brazilwood and weld as minor ingredients. In the black cloths samples, tannins were used in combination with yellow dyes from weld (or equivalent), young fustic or old fustic, and possibly iron/ copper salts and alum as mordants, as well as combined with red dyes from sandalwood, mordanted with iron and alum (sample W69). Of the samples examined in this study, dyes from young fustic and sandalwood were only encountered in this archive.

From the Crafts of Linen Weavers, Passementary and Ribbon Trimmings Archive (1700-1757), five black yarns sampled from striped fabrics were analysed. Tannin and logwood are found as the main ingredients, indicating a different dyeing procedure than found in the samples of the previously described striped textiles also dating from the eighteenth century (Table 1).

Samples W35 and W35b are dyed with logwood only, perhaps combined with iron and/or copper mordants. A more complex mixture of dyes was found in samples W35a and W60 with, respectively, tannin, logwood and madder, and tannin, logwood and weld as main ingredients, perhaps combined with iron and/or copper mordants. Sample W36 is the only sample from this archive that was not dyed with logwood, but with tannin and a trace of old fustic on an iron mordant.

The ingredients found correspond to the time frame of the samples, when dyeing wool with logwood and iron in combination with other ingredients to shade the wool was permitted.

In the Knijff Family Archive (1683-1696), tannins, only (sample W92) or together with brazilwood (sample W38a) or with logwood and madder (sample W38), are the main dye ingredients identified in this archive, while yellow dyes from dyer's greenweed and old fustic are present as minor ingredients, possibly combined with iron salts (Table 1).

The simple technique used to dye black in the nineteenth century is in sharp contrast to the complex methods used in the last quarter of the seventeenth and the eighteenth century. Unfortunately, this could only be deduced from the analyses of a few nineteenth century samples from the Industrial Tribunal Archive, dated from 1868, all dyed with logwood on an iron mordant (Table 1). However, it does correspond completely with information known from literature sources [21].

\section{Historical samples attributed to a certain period}

\section{Two Anonymous sample books, Fashion Museum Antwerp}

The two black yarns from the sample book dated to the first half of the eighteenth century have logwood and indigo/woad as main ingredients in sample W30, together with tannin and brazilwood as other important dye sources. Madder, weld, and old fustic were used as minor sources. Logwood was also the main ingredient of the samples from the second sample book dated from the first half of the nineteenth century. Other important dye sources used were dyer's greenweed (sample W59) and tannin (sample WT99/103). In the latter sample, cochineal, brazilwood, old fustic as well as indigo/woad were found as minor ingredients, while iron, copper and aluminium were detected which might refer to applied metal mordants. This complex mixture of organic dye sources and inorganic metal mordants detected in the last sample could be an indication of an over-dyeing of a previously incorrectly dyed fabric.

Anonymous Archive Municipal Museum Lokeren, (1870-1890)

Logwood is again the main ingredient of eight samples from the two sample books dated from 1870-1890. It was just not used in sample W77, which was dyed with mainly indigo/woad and tannin. In five samples, logwood was the only main dye source; in twice it was found in combination with indigo/woad and once with tannin. Brazilwood, madder, old fustic and indigo/woad were detected as minor ingredients and dyeing occurred most likely in the presence of iron/copper mordants.

The combination of both logwood and indigo together with red and/or yellow dyes, in this case madder or old fustic, was described by Cardon and is called le noir de Sedan. This method was used in the town of Sedan (Northern France) from the seventeenth century. It involved a combination of dyeing an undertone of indigo over-dyed with logwood in combination with sumac and copper mordant used in the saddening bath [19, p. 147].

In the currently brown-black sample W76, only a very small amount of the marker dye from logwood was found, without any other dye compounds, which might be explained by a lack or homogeneous application of an iron mordant on the fibres. 


\section{Historical artefacts}

Two black samples from the bonnets and pieces of cloth from Agnes Baliques were dyed with logwood and iron (W81) or iron and copper as mordant (sample W82), while sample W80 was dyed with logwood, tannin and iron, and sample W79 with tannin in combination with indigo/woad and iron. The two last samples were likely dyed with tannin on an undertone made of, respectively, logwood and indigo/woad. The variations in dyeing recipes found in the few historical artefacts samples, all from the same provenance, are striking. No additional yellow or red dyes were detected, which might be a deliberate choice of the dyers or due to the more pronounced degradation of these textiles.

\section{Conclusion}

The ingredients identified by chemical analyses performed on the black and dark brown dyed woollen samples from the historical Belgian archives and artefacts are largely consistent with the ingredients mentioned in the historical recipes and regulations for the 1650-1850 period. A qualitative overview of the eleven biological dye sources found together with the frequency of detection is given in figure 10. This figure demonstrates that logwood and tannins (galls, sumac or others) are by far the most popular ingredients, found in, respectively, 37 and 36 out of the 51 historical samples analysed.

Even more variation than expected is found in dye ingredients by HPLC analysis of the historical samples from the historical sources. When considering only the main organic dye ingredients for black dyeing (logwood, tannin, indigo/woad and madder), many samples were dyed with a combination of two or three of these ingredients. Another important constant in the HPLC results is that multiple yellow and red dyes were often detected. Of the yellow dye sources, old fustic and dyer's greenweed were most frequently detected, followed by weld and young fustic, while madder, brazilwood (also called redwood), Mexican cochineal and sandalwood were identified (in decreasing frequency) as red dye sources. It is likely that these dyes have been added to the dye bath to obtain a specific black shade or to bridge colour differences due to the reuse of dye baths or to previously incorrectly dyed textiles.

There is no general pattern of evolution in ingredients used over time. Logwood, indigo/woad, madder and tannin were used interchangeably during the 1680-1850 period. However, apart from one exception (sample W77), dye recipes without logwood only occur until the end of the eighteenth century.

Iron was detected frequently, perhaps indicative for the use of iron salts. Furthermore, iron was detected much more often than copper, or mixtures of both ingredients. The use of an iron-based mordant with a higher copper content was only noticed in the eighteenth and nineteenth century (in 1720-1820 and 1850-1890) (Figure 9).

The identified organic and inorganic ingredients from the analyses of the historical samples made it possible to situate the samples among the three main types of dyeing that can be distinguished from the written sources (Figure 11).

Dye recipes from type I with indigo and madder as main ingredients (without any addition of logwood) are rather rare. In fact, they were only detected in four samples from Book T94/187 from the Melijn archive dated from

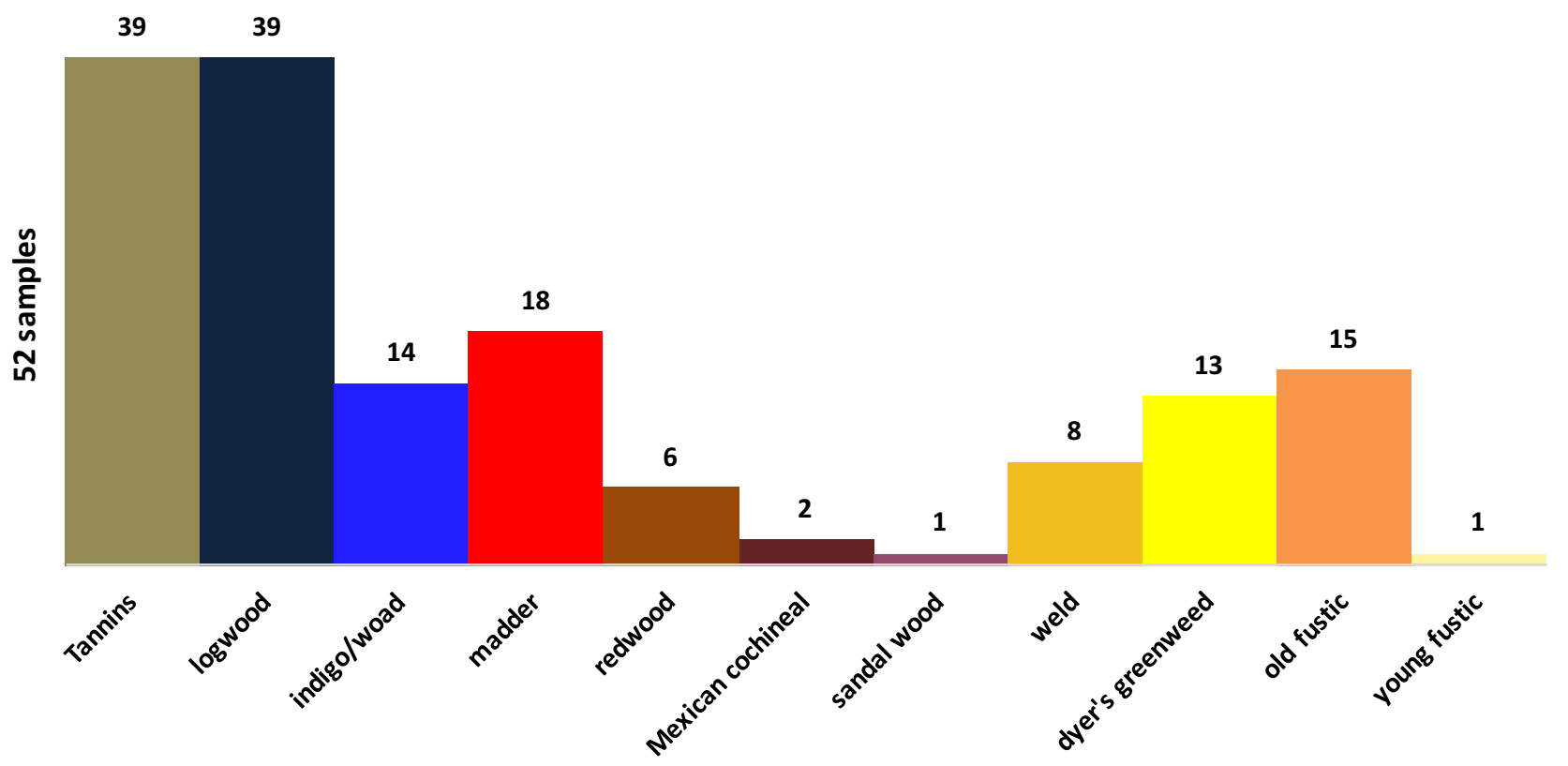

Figure 10. Biological sources in black dyed wool, 1650-1850. 


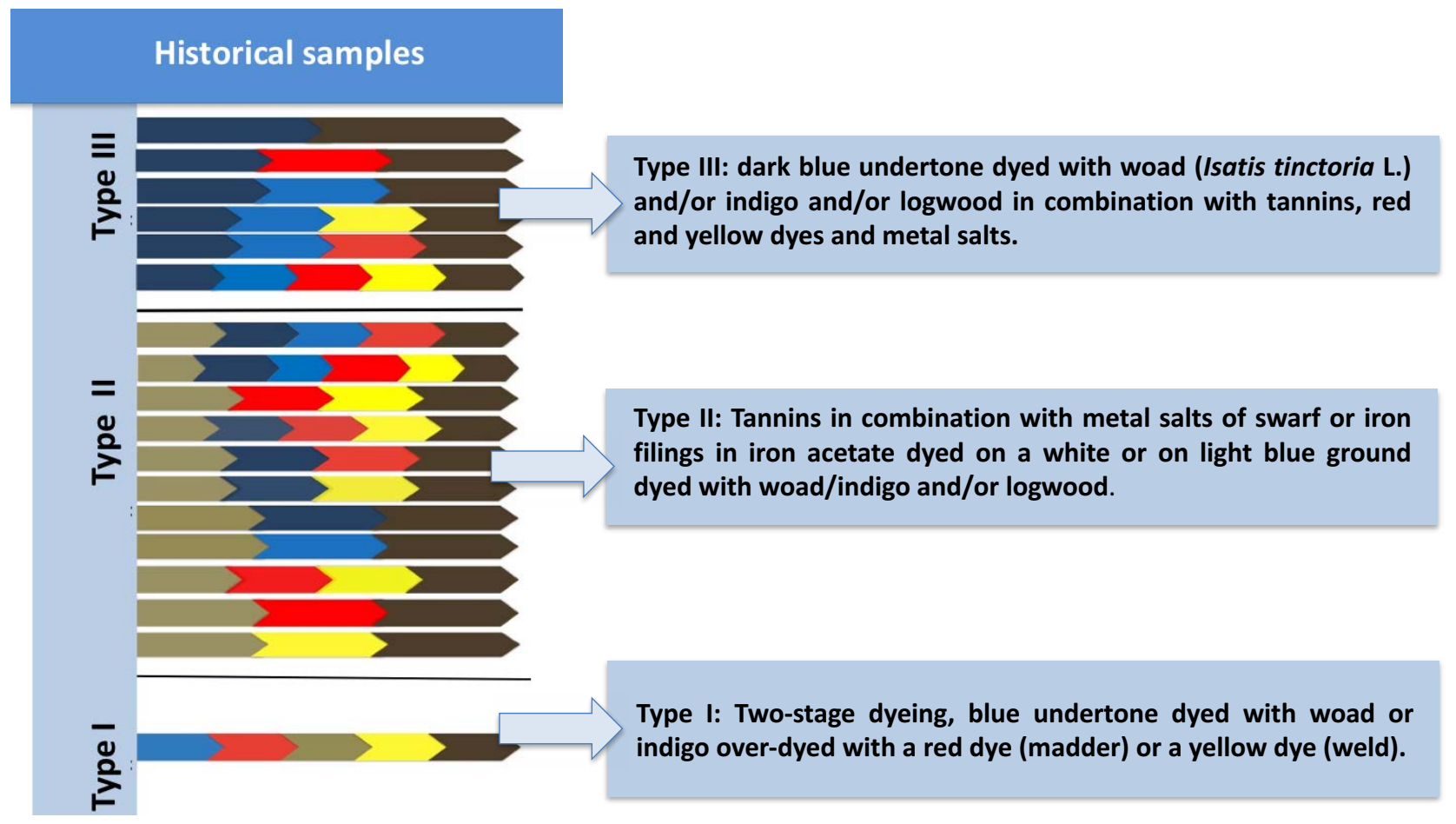

Figure 11. Typology of dyeing recipes based on the organic and inorganic ingredients identified in the historical woollen samples from the Belgian Archives (1650-1850).

1695. Black dyeing with tannin and metal salts (without the addition of logwood) (type II) was detected more frequently, mostly in combination with red dyes and/or yellow dyes and only twice in combination with indigo/woad alone. The dye recipes in which indigo/woad and/or logwood were used as blue undertone followed by a second dyeing with tannin together with red and/or yellow mordant dyes, likely also combined with metal salts (type III), were encountered regularly during the whole considered period. They provide clear evidence that dyeing black was even more complicated than literature suggests.

It is certain that the black dyers must have had very good technological skills in order to obtain the specific black shade in question with so many different ingredients, taking into account the possible quality variations of each of these natural raw materials.

\section{Acknowledgements}

The authors would like to thank Wim Mertens, curator of the Fashion Museum Antwerp, Anita Quye, Centre for Textile Conservation and Technical Art History, University of Glasgow, and the research group Heritage \& Sustainability of the University of Antwerp. Further thanks are due to the archivists and conservators of the Municipal Museum Lokeren, City Archive Antwerp, Belgian National Archive, Fashion Museum Antwerp and Convent of the Women Apostles of Antwerp.

\section{ORCID}

Ina Vanden Berghe

(iD) https://orcid.org/0000-0002-2053-6000
Olivier Schalm

(iD) https://orcid.org/0000-0001-8705-7293

\section{References}

1 Ortega Saez, N., 'Black dyed wool in North Western Europe, 1680-1850: The relationship between historical recipes and the current state of preservation', PhD-thesis, University of Antwerp (2018).

2 Braeckman, W. L., Middelnederlandse Verfrecepten Voor Miniaturen en 'Aller- Hande Substancien', Scripta, Gent (1986).

3 Brunello, F., The Art of Dyeing in the History of Mankind, Neri Pozza, Vicenza (1973).

4 Albo, J., Instructions Générales Pour la Teinture des Laines et des Manufactures de Laine de Toutes Couleurs et Pour la Culture des Drogues ou Ingrediënts qu'on y Emploie, Paris (1671).

5 De Beunie, J. B., Antwoord op de Vraege, Brussels (1772).

6 De Nie, W. L. J., 'De ontwikkeling der Noord-Nederlandsche textielververij van de veertiende tot de achttiende eeuw', thesis, Leyden (1937).

7 De Poerck, G., La Draperie Médiévale en Flandre et en Artois. Technique et Terminologie, 3 vols., De Tempel, Bruges (1951).

8 Dieu, M., 'Het verven der goederen te Leuven', De Brabantsche Folklore 11 (1932) 146-150.

9 Edelstein, S. M.; Borghetty, H. C. (transl.), The Plictho. Instructions in the Art of the Dyers Which Teaches the Dyeing of Woolen Cloths, Linens, Cottons, And silk by the Great Art as Well as by the Common, The M.I.T. Press, Cambridge (1969).

10 Edelstein, S. M., 'The Allerley Matkel - Study of earliest printed book on spot removing and dyeing, American Dyestuff Reporter 54 (1965) 297-321. 
11 Edelstein, S. M., 'Dyeing fabrics in sixteenth-century Venice', Technology and Culture 7 (1966) 395-397, https://doi. org/10.2307/3101938.

12 Frencken, H. G. T., 'T Bouck và wondre (1544, Antwerp, Cock)', PhD dissertation, University of Leiden (1934).

13 Grison, T., La Teinture au Dix-neuvième Siècle: en Ce qui Concerne la Laine et les Tissus ou la Laine est Prédominante, 2 vols., Paris (1884).

14 Hellot, J., Art de la Teinture des Laines et des Etoffes de Laine en Grand et en Petit Teint, Paris (1750).

15 Partridge, W., A Practical Treatise on Dying of Woollen, Cotton and Skein Silk: with the Manufacture of Broadcloth and Cassimer, Walker \& Co., New York (1823).

16 Ploss, E. E., Ein Buch von alten Farben, Technologie der Textilfarben im Mittelalter mit Einem Ausblick auf die Festen Farben, Impuls Verlag Heinz Moos, Heidelberg (1962).

17 Schweppe, H., Handbuch der Naturfarbstoffe, Vorkommen, Verwendung, Nachweis, Ecomed, Landsberg-Lech (1992).

18 Munro, J., 'Necessities and luxuries in early-modern textile consumption: real values of worsted says and fine woollens in the sixteenth century Low Countries', in Cities, Coins, Commerce: Essays Presented to Ian Blanchard on the Occasion of his 70th Birthday, ed. P. R. Rössner, Franz Steiner, Stuttgart (2012) 121-147.

19 Cardon, D., Natural Dyes: Sources, Tradition, Technology and Science, Archetype, London (2007).

20 Hofenk De Graaff, J. H., The Colourful Past, Origins, Chemistry and Identification of Natural Dyestuffs, Archetype Publications, London (2004).

21 Takami, M.; Vanden Berghe, I., 'Caring for Queen Victoria's Privy Council dress c.1837: an investigation of the unique discolouration of the black silk', e-Preservation Science $\mathbf{1 0}$ (2013) 42-49.

22 Quye, A.; Hallett, K.; Herrero Carretero, C., Wroughte in Gold and Silk. Preserving the Art of Historic Tapestries, National Museums of Scotland, Edinburgh (2009).

23 Thijs, A. K. L, 'Van 'werkwinkel' tot 'fabriek'. De textielnijverheid te Antwerpen van het einde der vijtiende tot het begin der negentiende eeuw', PhD thesis, Antwerpen (1987).

24 Saverwyns, S.; Vanden Berghe, I., 'Separation techniques in archaeometry', in Analytical Archaeometry. Selected Topics, ed. H. Edwards \& P. Vandenabeele, RSC Publishing, Cambridge (2012) 132-162, https://doi. org/10.1039/9781849732741-00132.

25 Degano, I.; Ribechini, E.; Modugno, F.; Colombini, M. P. 'Analytical methods for the characterization of organic dyes in artworks and in historical textiles', Applied Spectroscopy Reviews 44 (2009) 363-410, https://doi. org/10.1080/05704920902937876.

26 Petroviciu, I.; Vanden Berghe, I.; Cretu, I.; Albu, F.; Medvedovici, A., 'Identification of natural dyes in historical textiles from Romanian collections by LC-DAD and LC-MS (single stage and tandem MS)', Journal of Cultural Heritage 13 (2012) 89-97, https://doi.org/10.1016/j.culher.2011.05.004.

27 Surowiec, I.; Quye, A.; Trojanowicz, M., 'Liquid chromatography determination of natural dyes in extracts from historical Scottish textiles excavated from peat bogs', Journal of Chromatography A 1112 (2006) 209-217, https:// doi.org/10.1016/j.chroma.2005.11.019.

28 Vanden Berghe, I.; Gleba, M.; Mannering, U., 'Towards the identification of dyestuffs in Early Iron Age Scandinavian peat bog textiles', Journal of Archaeological Science 36(9) (2009) 1910-1921, https://doi.org/10.1016/j.jas.2009.04.019.

29 Mantzouris, D.; Karapanagiotis, I.; Valianou, L.; Panayiotou, C., 'HPLC-DAD-MS analysis of dyes identified in textiles from Mount Athos', Analytical and Bioanalytical Chemistry
399 (2011) 3065-3079, https://doi.org/10.1007/s00216-0114665-4.

30 Gleba, M.; Vanden Berghe, I.; Aldenderfer, M., 'Textile technology in Nepal in the 5th-7th centuries CE: the case of Samdzong, Science \& Technology of Archaeological Research 2(1) (2016) 1-11, https://doi.org/10.1080/20548923.2015.1110421.

31 Kramell, A.; Li, X.; Csuk, R.; Wagner, M.; Goslar, T.; Tarasov, P. ; Kreusel, N.; Kluge, R.; Wunderlich, C.-H., 'Dyes of late Bronze Age textile clothes and accessories from the Yanghai archaeological site, Turfan, China: Determination of the fibres, colour analysis and dating', Quaternary International 348 (2014) 214-223, https://doi.org/10.1016/j. quaint.2014.05.012.

32 Wouters, J., 'A new method for the analysis of blue and purple dyes in textiles', Dyes in History and Archaeology 10 (1992) 17-21.

33 Koren, Z., 'A new HPLC-PDA method for the analysis of Tyrian Purple components', Dyes in History and Archaeology 21 (2008) 26-35.

34 Karapanagiotis, I., 'Identification of indigoid natural dyestuffs used in art objects by HPLC couple to APCI-MS', American Laboratory 38(3) (2006) 36-40.

35 Mantzouris, D.; Karapanagiotis, I.; Panayiotou, C., 'Comparison of extraction methods for the analysis of Indigofera tinctoria and Carthamus tinctorius in textiles by high performance liquid chromatography', Microchemical Journal 115 (2014) 78-86, https://doi.org/10.1016/j.microc.2014.02.010.

36 Karatzani, A., 'Study and analytical investigation of metal threads from Byzantine/Greek ecclesiastical textiles', $X$-Ray Spectrometry 37 (2008) 410-417, https://doi.org/10.1002/ xrs.1021.

37 Melijn Archive, Fashion Museum Antwerp (1681-1714).

38 De Ridder L., De Godminnende Agnes Baliques, Stichtster der Vergadering der Dochters van de Onbevlekte Ontvangenis der Allerheilige Maagd en Moeder Gods Maria (Genaamd Apostellinnen), Algemeen Rijksarchief, Brussel (1996).

39 Ortega Saez N., The Technology of Black Dyeing, Exhibition catalogue Masters of Black in Fashion \& Costume, MOMU Antwerp (2010).

40 Peggie, D. A.; Kirby, J.; Poulin, J.; Genuit, W.; Romanuka, J.; Willis, D. F.; De Simone, A.; N. Hulme, A., 'Historical mystery solved: a multi-analytical approach to the identification of a key marker for the historical use of brazilwood (Caesalpinia spp.) in paintings and textiles', Analytical Methods 10 (2018) 617-623, https://doi.org/10.1039/C7AY02626A.

41 Wouters, J.; Verhecken, A., 'The Coccid insect dyes. HPLC and computerized diode-array analysis of dyed yarns', Studies in Conservation 34 (1989-1990) 189-200, https://doi. org/10.1179/sic.1989.34.4.189.

42 Vanden Berghe, I., 'The identification of cochineal species in Turkmen weavings; a special challenge in the field of dye analysis', in Turkmen Carpets. A New Perspective, ed. Jürg Rageth, Freunde des Orientteppichs, Basel (2016) 303-310, 333-348.

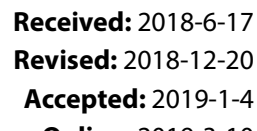

Online: 2019-3-10

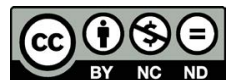

This work is licensed under the Creative Commons Attribution-NonCommercial-NoDerivatives 4.0 International License. To view a copy of this license, visit http://creativecommons.org/licenses/by-nc-nd/4.0/deed.en. 